CAHIER DE RECHERCHE \#1513E

WORKING PAPER \#1513E

Département de science économique

Department of Economics

Faculté des sciences sociales

Faculty of Social Sciences

Université d'Ottawa

University of Ottawa

\title{
Ethnic Inequality: Theory and Evidence from Formal Education in Nigeria*
}

\author{
Pritha $\mathrm{Dev}^{\dagger}$, Blessing U. Mberu and Roland Pongou ${ }^{\S}$
}

December 2015

\footnotetext{
*An earlier version of this paper circulated under the title : "Communitarianism, Oppositional Cultures, and Human Capital Contagion: Theory and Evidence from Formal versus Koranic Education.” We are grateful to Gamal Atallah, David Autor, Victoria Barham, Lori Beaman, Moussa Blimpo, Serge Coulombe, Yazid Dissou, Steven Durlauf, Christian Ebeke, Fernanda Estevan, Marcel Fafchamps, Andrew Foster, Gilles Grenier, Renate Hartwig, Louis Hotte, Najib Khan, Mariko Klasing, Christopher Ksoll, Paul Makdissi, Ted Miguel, Petros Milionis, LouisPhilippe Morin, Muthoni Ngatia, Dozie Okoye, Louis Putterman, Debraj Ray, Daniel Rosenblum, Roberto Serrano, Pedro Vicente, Leonard Wantchekon, Myra Yazbeck, and Thierry Yogo for comments and encouragement. We also thank seminar participants at ITAM, the University of Ottawa, and Dalhousie University, and conference participants at the 2012 CSAE Meeting at the University of Oxford, the 2012 EEA-ESEM Meetings in Málaga, and the 2013 North American Winter Meeting of the Econometric Society in San Diego. Part of this project was completed when Dev was at ITAM, Mexico, and she thanks this institution for its generous support. Pongou gratefully acknowledges the Social Sciences and Humanities Research Council of Canada grant 230614-1902992001, and thanks the Department of Economics of the University of Oxford for hospitality.

† Indian Institute of Management Ahmedabad, Vastrapur, Ahmedabad, 380015; email: pritha@iimahd.ernet.in.

‡APHRC; email: bmberu@aphrc.org.

§ Department of Economics, University of Ottawa, Ontario, K1N 6N5, Canada; email: rpongou@uOttawa.ca.
} 


\begin{abstract}
We study the causes of inequality in human capital accumulation across ethnic and religious groups. An overlapping generations model in which agents decide how much time to invest in human capital versus ethnic capital shows that the demand for human capital is affected positively by parental and group's older cohort human capital, and negatively by group size. Two ex-ante identical groups may diverge in human capital accumulation, with the divergence mostly occurring among their low-ability members. Furthermore, group and ethnic fragmentation increases the demand for human capital. We validate these predictions using household data from Nigeria where ethnicity and religion are the primary identity cleavages. We document persistent ethnic and religious inequality in educational attainment. Members of ethnic groups that historically converted to Christianity outperform those whose ancestors converted to Islam. Consistent with theory, there is little difference between the high-ability members of these groups, but low-ability members of historically Muslim groups choose Koranic education as an alternative to formal education, even when formal education is free. Moreover, more religiously fragmented ethnic groups fare better, and local ethnic fragmentation increases the demand for formal education. Our analysis sheds light on the political context that underlies the recent violent opposition to "western education" in this country.
\end{abstract}

Key words: Group Inequality, Human Capital, Ethnic Capital, Ethnic networks, Ethnic Politics, Koranic Education.

JEL Classification: A13, D9, I21, I24, N3, O1.

\title{
Résumé
}

Nous étudions les causes de l'inégalité dans l'accumulation de capital humain entre les groupes ethniques et religieux. Un modèle à générations imbriquées dans lequel les agents décident de leur investissement dans l'acquisition du capital humain comparativement au capital ethnique montre que la demande pour le capital humain est affectée positivement par le capital humain des parents et de la cohorte précédente du groupe, et négativement par la taille du groupe. Nous trouvons aussi qu'il est possible que deux groupes initialement identiques divergent dans l'accumulation du capital humain à l'équilibre, la divergence étant plus prononcée chez les membres qui ont peu d'habilité. De plus, la fragmentation d'un groupe ainsi que la fragmentation ethnique augmente la demande pour le capital humain. Nous testons ces résultats avec les données sur les ménages collectées au Nigeria, un pays où l'ethnicité et la religion sont les deux principaux indicateurs du clivage social. Nous documentons une forte inégalité entre les groupes ethniques et religieux dans le niveau d'éducation. Les membres des groupes ethniques historiquement convertis au christianisme ont de meilleures performances que ceux dont les ancêtres étaient convertis à l'Islam. En accord avec la théorie, il y a peu de différence entre les individus qui ont une habilité élevée, mais les membres des groupes historiquement musulmans qui ont une faible habilité choisissent l'éducation coranique comme une alternative à l'éducation formelle, et ce même lorsque l'éducation formelle est gratuite. De plus, les membres des groupes où il existe une forte hétérogénéité religieuse s'en sortent mieux, et la fragmentation ethnique locale augmente la demande d'éducation formelle. Notre analyse met en lumière le contexte politique qui explique la récente opposition radicale à l' " éducation occidentale » dans ce pays.

Mots clés : Inégalité entre les groupes, capital humain, capital ethnique, réseau ethnique, politiques ethniques, éducation coranique.

Classification JEL : A13, D9, I21, I24, N3, O1. 


\section{Introduction}

Inequality across social groups with distinct identities and cultures is one of the most important issues facing modern societies. Disparities in economic opportunities, employment, earnings, and asset holding are generally perceived as symptoms of discrimination against the less well-off groups, which often leads to social animosities, riots, and violent conflicts. ${ }^{1}$ In a perfectly competitive market economy, group inequality partly results from group differences in the level of human capital. A large body of literature has suggested that such differences are in part attributable to cultural factors (e.g., Ogbu (1978), Fordham and Ogbu (1986), Fordham (1996), Austen-Smith and Fryer (2005)), with some groups adopting an oppositional attitude towards formal education, and others encouraging or pressuring their members into intensive community activities that leave little time for human capital acquisition. Given the grave social consequences of individual and group inequality, undertaking an analysis of the individual and group factors that influence the educational choice of individuals is important for informing the design of public policy.

In this paper, we analyze the implications of people to organize into culturally homogeneous groups which act as closed networks for individual and group inequality in human capital accumulation. The set of potential groups arises exogenously, but adherence to group values is endogenous. Education, through which human capital is built, is promoted by a secular state as a universal value. Each individual chooses how much time to invest in acquiring formal education (or human capital) and how much to invest in strengthening his relationship with his ethnic group (ethnic capital). We study the determinants of such a choice, focusing on the interplay of individual characteristics such as ability with group characteristics such as group size and ability. From our findings, we also identify a new mechanism through which social fragmentation affects human capital demand. We test the theoretical predictions using nationally representative household data from Nigeria, where ethnicity and religion are the primary identity cleavages.

Nigeria has over 250 ethnic groups ${ }^{2}$ and counts numerous religious denominations which can be categorized as Christian and Muslim. There is a long documented history of a diverging attitude of Christians and Muslims towards formal education in this country. This reality is evidenced in Figure 1-A, which shows the Christian-Muslim gap in formal educational attainment by age. Muslims are at a disadvantage early on, and fall further behind over time, lagging Christians by more than 4 years of education by age 24 . There is also a great deal of inequality in educational attainment between ethnic groups. Figure 2-A shows that Yoruba, Niger-Delta, and Igbo children, with 10 years of education by age 24, are consistently more educated than the Middle-Belt (8 years) and the Hausa/Fulani/Kanuri (4 years). These inequalities continue to persist even after the supply of educational infrastructure at the neighborhood level is accounted for (see Figure 1-B and Figure 2-B).

Why is ethnic inequality in educational attainment so high in Nigeria? Given the diverging attitude

\footnotetext{
${ }^{1}$ See, e.g., Esteban and Ray (2011), Mitra and Ray (2014), and Sen (1973).

${ }^{2}$ It is common to aggregate the different ethnic groups based on linguistic and cultural affinities into five major categories: The Hausa/Fulani/Kanuri of the core North, the Igbo of the South East, the Yoruba of the South West, the Isoko/Urhobo/Edo/Ijaw/Efik/Ibibio of the Niger-Delta region, and the Tiv/Igala/Idoma/Gwari of Central Nigeria, also known as the Middle-Belt region (NISER (1997)).
} 
of Christians and Muslims towards formal education, part of the answer could be found in the fact that religious affiliation varies a great deal across ethnic groups in this country. Indeed, Figure 3 shows that Christians are more concentrated among the Igbo, the Niger-Delta, and the Middle-Belt, whereas Muslims are more concentrated among the Hausa/Fulani/Kanuri. Clearly, ethnic groups that invest more in formal education are predominantly Christian. In predominantly Muslim groups, children tend to invest heavily in Koranic education, losing ground with respect to investment in human capital. ${ }^{3}$ As Figure 4 shows, among the Hausa/Fulani/Kanuri, 23.5\% of children have only a Koranic education, in stark constrast to the Igbo (0.1\%), the Yoruba (0.4\%), the Niger-Delta (0.4\%), and the Middle-Belt $(2.7 \%)$. Clearly, Koranic education is an important alternative to formal education.

The evidence therefore suggests that religious attitude towards formal education may explain ethnic inequality in educational investment in Nigeria, but it may not explain it all. In fact, despite the fact that Muslims are far more represented among the Yoruba (46\% of the Yoruba are Muslim) than among the Igbo $(0.3 \%)$, the Niger-Delta $(2.4 \%)$, and the Middle-Belt (31\%), Yoruba children perform better than children in these other ethnic groups. This suggests that there are other driving forces of group inequality. And even if attitude towards formal education were the only explanatory factor of group inequality, one would still wonder why such attitude varies so much across groups. Why are certain groups more likely to invest in ethnic capital than others? Why are the Middle-Belt children seven times more likely than their Yoruba counterparts to choose Koranic education over formal education despite having a much smaller proportion of Muslims? What are the main driving forces of group inequality?

Our goal is to answer these questions. We develop an overlapping generations model of a society composed of two ethnic groups. ${ }^{4}$ Each individual belongs to one ethnic group and makes a decision of whether to invest in ethnic capital or human capital. By investing in ethnic capital, we mean that the individual either attends schools run by the community, or works towards learning a particular skill in which the ethnic group specializes. Investing in ethnic capital makes the individual eligible for work in the ethnic labor market where he competes only with other members of his own ethnic group who also invested in ethnic capital. The benefit to the individual from such an investment is the wages he earns in the ethnic labor market. These wages depend on the number of people of his ethnicity who also invest in ethnic capital and the size of resources controlled by his ethnic group, which we call ethnic wealth. By investing in human capital, we mean that the individual attends state-run school to acquire formal education. Such an investment makes the individual eligible for work in the formal labor market where he competes with all individuals, irrespective of ethnicity, who also invested in human capital. The benefit to the individual from investing in human capital depends on the wages in the formal labor market, which are a function of the total number of people from all ethnic groups who invest in human capital.

We further assume that the cost of acquiring education decreases with higher ability and total human capital investment by the older cohort of the same ethnic group. The motivation is that

\footnotetext{
${ }^{3}$ Koranic education is one of the many forms of ethnic capital that exist in Nigeria.

${ }^{4}$ In the model, ethnic groups are also meant for religious and ethno-religious groups. In the empirical analysis, we show the effects of both ethnicity and religion on the outcome.
} 
the older cohort from the same ethnic group may help the current cohort in the skill acquisition process, implying that the greater the size of the educated older cohort, the greater are the benefits for all members of the current cohort. We later weaken this assumption by allowing for cross-ethnic interactions where each individual's cost of human capital acquisition depends on a weighted average of the levels of human capital from different ethnic groups. ${ }^{5}$

The model generates testable predictions. First, it shows that two groups that are ex-ante identical may diverge in human capital accumulation (T1). Hence, groups that are similarly sized, begin with the same level of ethnic wealth, and have the same distribution of ability amongst their members might in equilibrium have very different levels of human capital. Second, if two groups differ in human capital accumulation, this difference mostly occurs among the low-ability members of both groups, since the very able members from any ethnic group can always choose the more rewarding investment in human capital (T2). Third, we find that an individuals's demand for human capital is positively affected by the ability (or human capital) of his parents and that of the older generation of his ethnic group (T3). Fourth, an individual's human capital is negatively affected by the wealth of his ethnic group (T4). In an ethnic democracy such as Nigeria, the wealth of a group is correlated with its size, as larger ethnic groups have more political power, enabling them to extract more resources. Fifth, allowing ethnic wealth to be a function of group size, we find that ethnic and group fragmentation positively affects the demand for human capital (T5). When we allow for cross-ethnic interactions, we see that, under certain conditions, higher levels of cross-ethnic interaction reduce the difference in levels of human capital between ethnic groups.

We test these predictions of the model using nationally representative household data from Nigeria. First, we seek to explain cross-group differences in formal educational performance, testing prediction (T1). They may be attributable to demographic and socioeconomic conditions that are known to vary across ethnic groups in most countries. In multivariate analyses, we therefore control for a range of individual and household level demographic and socioeconomic variables. The advantage of the Yoruba over other ethnic groups declines in magnitude, but remains statistically significant.

Given that the formal educational infrastructure may not be evenly supplied across different regions, the remaining differences could be due to the fact that some ethnic groups benefit more than others. To address this issue, as in Figures 1-B and 2-B, we control for neighborhood fixed effects, in the assumption that individuals residing within the same neighborhood have the same exposure to educational supply. ${ }^{6}$ We find that the differences between the Yoruba, the Igbo and the Niger-Delta no longer persist, but the Middle-Belt and the Hausa/Fulani/Kanuri still lag behind the Yoruba.

The cost of formal education might prevent members of certain groups from enrolling in school. To address this issue, we exploit the fact that enrollment in public primary schools was declared free in Nigeria in 1999. This measure was most likely to impact younger individuals. We therefore estimate

\footnotetext{
${ }^{5}$ These assumptions remind the "strategic complementary" assumption well known in the literature (see, e.g., Glaeser and Scheinkman (2000) on some of its formulations). See also Belhaj and Deroian (2011) for similar assumptions in a context in which agents allocate time between two activities. Our assumptions imply within-group strategic complementarity in ethnic capital and both within-group and across-group complementarity in human capital.

${ }^{6} \mathrm{~A}$ neighborhood in the data is a small area, similar to a census tract.
} 
the effect of ethnicity on education for distinct age groups, finding that the Yoruba, the Igbo, the Niger-Delta and the Middle-Belt aged 5-9 years do not differ in their educational attainment, but the disadvantage of the Hausa/Fulani/Kanuri remains economically and statistically significant across all the age groups

The diverging outcome of the Hausa/Fulani/Kanuri is consistent with the prediction stated in (T1) based on the existence of multiple equilibria. Indeed, that the Hausa/Fulani/Kanuri individuals continue to lag behind after we control for a range of factors clearly corroborates our earlier observation that investment in ethnic capital (often in the form of religious education) is heavier in that group as compared to other groups. However, according to prediction (T2), high-ability individuals are more likely to choose human capital over ethnic capital regardless of their group attachment to an oppositional norm. This implies that cross-ethnic differences in educational performance should be smaller among high-ability individuals and more pronounced among those of low ability. We test and validate this theoretical prediction, using parental education and wealth as measures of ability. ${ }^{7}$ Furthermore, to control for common religious factors inherent in Islam, we replicate this test for Muslim individuals only, and we find that the poor performance of Hausa/Fulani/Kanuri children relative to all other groups persists only for those children whose parents have no education or are very poor, clearly corroborating prediction (T2).

We also validate our third prediction according to which an individual, regardless of his ability, is more likely to invest in human capital if his parent's human capital or that of the older cohort of his group is high (T3). We measure a group's older cohort's human capital by the neighborhood-level share of adults in that group with at least a secondary school education. We validate the prediction, finding, for example, that a one-point increase in the neighborhood share of educated Hausa/Fulani/Kanuri adults increases education by 5.2 years among Hausa/Fulani/Kanuri children, but has little effect on children from other tribes. In general, these effects are mostly confined within ethnic groups, showing a clear network effect.

Next, we test the prediction that individuals belonging to smaller ethnic groups are more likely to invest in human capital than those belonging to larger groups (T4). We test this prediction in two different ways. First, we construct a binary variable for minority status based on whether an individual belongs to the minority religion within his ethnic group (for instance, a Muslim Igbo is considered a minority whereas a Christian Igbo is a majority). Consistent with the theory, we find that minorities invest more in formal education. Second, we estimate the effect of an individual's ethnic group representation in his neighborhood on his educational attainment, and find that individuals belonging to smaller groups perform better than those belonging to larger groups.

\footnotetext{
${ }^{7}$ Measuring a child's ability by the education and wealth of his parents is standard in the literature. It is argued that higher-ability parents can help their children with homework, facilitating human capital acquisition. According to a very large literature in Biology and Labor Economics, parental education and wealth have a direct impact on child ability as measured by IQ and cognitive and non-cognitive skills (Løken, Mogstad and Wiswall (2011), Currie (2009), Currie and Moretti (2003), Lundborg, Nilsson and Rooth (2012), Almond and Currie (2011)). Indeed, higher parental SES has a positive effect on a range of children's health indicators (Case, Lubotsky and Paxson (2002), Glewwe (1999), Pongou, Ezzati and Salomon (2006), Pongou, Salomon and Ezzati (2006), Currie (2009)), and better health in childhood positively affects mental and cognitive ability (Weinreb et al. (2002), Glewwe and Jacoby (1993), Chang et al. (2002), Currie (2009), Currie and Stabile (2006), Currie (2000)), as well as productivity in adulthood (Currie et al. (2010)).
} 
As a corollary of the latter prediction, ethnic fragmentation should have a positive effect on the demand for formal education (T5). Indeed, we find that individuals who reside in more ethnically heterogeneous neighborhoods have more education. Interestingly, when we control both for the size of an individual's ethnic group and ethnic fragmentation, only the latter variable remains statistically significant, further validating the model mechanism that the positive effect of ethnic fragmentation on the demand for formal education is just a reflection of the positive effect of ethnic minority status on this outcome.

The rest of the paper is organized as follows. In Section 2, we situate our study within the literature. Section 3 presents the theoretical model and its predictions. We test the model in Section 4 , and conclude our study in Section 5.

\section{$2 \quad$ Related Literature}

Our paper is related to the literature on group inequality. Initiated by Becker (1957), Arrow (1973), and Phelps (1972), this literature has looked at sustained group inequality arising due to discrimination. Loury (1977), Durlauf (1996), and Benabou (1996) explain group inequality by segregation. Recent papers focus on education and occupational choice (see, e.g., Mookherjee et al. (2010a), Bowles et al. (2014)). Our paper finds that group inequality in educational investment can arise out of ex-ante identical conditions. This finding implies that inequality may not be explained by factors upon which policymakers can act. However, we also identify several tangible sources of inequality. Ethnic wealth (resources available to an ethnic group for productive activities), for instance, is a potential driver of differences in educational attainment across ethnic groups. We show theoretically that communities with lower ethnic wealth are more likely to choose investments in human capital over ethnic capital. A similar result can be seen in Munshi and Rosenzweig (2006) where they show that girls who are excluded from the benefits of ethnic wealth are more likely to invest in human capital. In Luke and Munshi (2011), it is shown that children from the lower castes who have lower ethnic wealth (in the form of caste-based insurance networks) are more likely to invest in a better education.

Our result that a child's human capital is partially determined by his parent's human capital as well as the average human capital of his ethnic community is consistent with Borjas (1992), who also argues that if parents' human capital differs by ethnicity, this is likely to persist across several generations. We also add new results to this literature. For instance, the finding that members of smaller groups are more likely to invest in human capital is new. Also, whereas ethnic fragmentation has been shown to decrease the "supply" of public goods (e.g., Easterly and Levine (1997), Miguel and Gugerty (2005)), our study shows that fragmentation increases the "demand" for human capital.

Our assumption that ethnic groups play the role of social networks through which members may obtain information about job opportunities is consistent with studies that have found social contacts to play an important role in labor market and other economic outcomes (Granovetter (1973, 1995), Fafchamps (2010)). Granovetter (1973) argues that new information flows to people through "weak ties", and Granovetter (1995) empirically shows that connections play an important role in job find- 
ing. The latter study is consistent with Fafchamps (2010) who, analyzing data from three African countries, finds that networks positively affect trust and information sharing, and that better connected individuals obtain more prosperous businesses. The assumption that connections matter has also motivated theoretical studies on the role of exogenous networks on employment and inequality (e.g., Calvó-Armengol and Jackson (2004, 2005), Montgomery (2001), Topa (2001)). Importantly, our empirical findings corroborate this assumption, as the positive effects of community human capital on youth education are mostly confined within ethnic groups.

Our paper contributes to the very large literature on conformity and the formation and persistence of identity, culture, and social norms. ${ }^{8}$ Akerlof and Kranton (2000) incorporate the psychology and sociology of identity into an economic model of behavior, and show that identity determines economic outcomes. In their model, identity is defined by "a person's self-image" and her assigned category, each category being characterized by a set of prescriptions and norms indicating the behavior to which individuals in the category should conform. Conforming to or deviating from her category-prescribed norms results in gains or losses in identity. The model sheds light on differences in school achievement across different categories of students. Bodenhorn and Ruebeck (2003) study the cost and benefits of adopting a mulato or a black racial identity among the African-American population in the midnineteenth century. Munshi and Wilson (2010) look at the role of identity in mobility. As in our model, they allow people to choose between two forms of capital accumulation, and this choice determines the probability of social mobility.

There are only a few empirical studies that examine the effect of identity on education and employment, and most of them focus on the U.S., Canada, and Europe (e.g., Fordham and Ogbu (1986), Ainsworth-Darell and Downey (1998), Fryer and Levitt (2004), Austen-Smith and Fryer (2005), Fryer and Torelli (2009), Constant and Zimmermann (2008), Pendakur and Pendakur (2005), CalvóArmengol, Pattachini and Zenou (2009)). With a notable exception (Ainsworth-Darell and Downey (1998)), there is a large consensus in these literatures that identity matters in determining outcomes, with those who adopt an oppositional culture or those who do not integrate or assimilate with the majority culture lagging behind.

Similar to those previous studies, our paper links ethnic and religious identity to educational choice in a country where active opposition against "western education" has been demonstrated in some population subgroups. However, our analysis, despite containing some of the elements of all these other studies (e.g., peers effects, strategic complementarity, etc.), differs in some important respects. Our main contribution consists of identifying important individual- and group-level determinants of human capital versus ethnic capital accumulation. First, our findings imply that group-level differences in human capital do not necessarily need to be explained by differences in initial attitude towards education or ability. In fact, as already mentioned, two ex-ante identical groups may end up having different levels of educational attainment (see prediction (T1)). The default explanation for such a divergence is that the two groups are separated. However, we also show that assimilation is not

\footnotetext{
${ }^{8}$ See, e.g., Bernheim (1994), Akerlof (1980), Bisin and Verdier (2000), Glaeser and Scheinkman (2000), Kandel and Lazear (1992), Fershtman and Weiss (1998), Kandori (1992), Akerlof (1980), and Currarini, Jackson and Pin (2008).
} 
a sufficient condition for convergence in human capital accumulation across groups, as two groups might still differ despite being perfectly assimilated. Second, by treating different ethnic groups as local economies as in Lundberg and Startz (1998), we show that smaller groups are more likely to invest in human capital. Importantly, this result implies that members of the same ethnic group who reside in different locations within a country are likely to differ with respect to how they accumulate human capital, with smaller subgroups faring better than larger subgroups. This result sheds light on the observation that second and subsequent generation migrants whose parents have left their region of origin to settle in another region within a country generally do better than their co-ethnics who have remained in their homeland. While this has usually been explained by the positive selectivity of migrants, our results suggest that the same outcome would obtain even if migrants do not differ from non-migrants in terms of ability distribution.

By showing that inequalities in human capital accumulation across ethnic and religious groups in Nigeria are partially due to the fact that certain members of historically Muslim communities choose Koranic education as an alternative to formal education, we prove that these inequalities are also a consequence of differential historical exposure to Christianity and Islam during the pre-colonial period. In this regard, our findings are consistent with studies on the historical origins of differences in cultures, norms, and economic outcomes (Guiso, Sapienza and Zingales (2008), Huillery (2009), Nunn (2009), Tabellini (2010), Nunn and Wantchekon (2011), Okoye and Pongou (2015)). In particular, studies on the long-run economic impacts of historical religious exposure have mainly focused on the effect of Protestantism. ${ }^{9}$ The economic effects of Islam have attracted less attention. Most of the few studies on this topic use cross-country data, and therefore cannot adequately separate the effect of religion from other country level factors that may affect outcomes. In contrast, we use household-level data that enable us to control for neighborhood fixed effects, allowing us to address endogeneity issues related to self-selection into certain areas or to the non-random supply of formal educational infrastructure.

We also find theoretically and empirically that local ethnic fragmentation, by creating smaller groups, positively affects the demand for formal education. Given the essential role of human capital in the production of wealth in technologically advanced societies (Gary Becker $(1962,1964)$, Galor and Weil (2000), Acemoglu (2009), Mincer (1974)), our results imply that local ethnic fragmentation may have a positive effect on local economic growth by positively affecting the likelihood that individuals pursue formal education. Other studies have shown that ethnic fragmentation slows economic growth and negatively affects the supply of public goods (e.g., Easterly and Levine (1997), Miguel and Gugerty (2005), Fernandez and Levy (2008), see Alesina and Ferrara (2005) and Costa and Kahn (2003) for a comprehensive review of literature). In general, these other studies postulate that different ethnic groups, for diverse reasons, find it difficult to cooperate in order to induce and/or enforce optimal economic policies. But the evidence on this is mixed. Using firm-level data, Ellison and Mullin (2014) show that more heterogeneous offices in a firm enjoy less social goods such as cooperation and satisfaction, but perform better than those that are more homogeneous. By proposing a new

\footnotetext{
${ }^{9}$ See, e.g., Barro and McCleary (2003, 2005), Blum and Dudley (2001), Guiso, Sapienza and Zingales (2003, 2006), George Becker (1997), Glaeser and Sacerdote (2008), Goldin and Katz (2000), Glaeser and Glendon (1998), Sascha Becker and Ludger Woessmann (2009).
} 
mechanism through which group and ethnic fragmentation affects human capital "demand", we view our theoretical and empirical findings as complementary to the existing body of research, which, unlike our study, has essentially focused on the effect of ethnic fragmentation on the "supply" of public goods. To our knowledge, our study is the first to document theoretically and empirically the effect of ethnic fragmentation on the "demand" for schooling.

\section{The Model}

\subsection{Setup}

Consider a discrete-time infinite sequence of generations where each generation lives for two periods, being active in the first period of existence and inactive in the second period. Let the active population each period be referred to as the current cohort and the inactive population as the older cohort. This population is of unit mass and indexed in the $[0,1]$ interval. Let there be two ethnic groups which are referred to as ethnic group 1 and ethnic group $2 .{ }^{10}$ The size of ethnic group 1 is $c$ and that of ethnic group 2 is $1-c$. For ease of notation, ethnic group $i \in\{1,2\}$ is said to have size $c_{i}$. In each period, each individual of the current cohort is matched to an inactive individual from the same ethnicity (e.g., a parent).

Each individual in the current cohort chooses his investment in either human capital or ethnic capital. Investing in human capital means that an individual gets a formal education and is able to participate in the formal labor market. The formal labor market is such that the returns to participants depend on all others (not necessarily from the same ethnicity) also participating in this market. On the other hand, an investment in ethnic capital means that the individual gets traditional/ethnic education and is eligible only to participate in the ethnic labor market. The ethnic labor market is such that the only participants are members of the same ethnic group who also choose ethnic capital. ${ }^{11}$

Ethnic labor markets in Nigeria arise due to ethnic groups focusing on certain businesses and trades; and investment in ethnic capital can be thought of as joining an apprentice system to learn the business/trade. A prominent feature of Igbo businesses, located in Nigeria's large and medium urban centers, is the phenomenon of apprenticeship. Chukwuezi (2001) shows that career trajectories of majority of Igbo businessmen started off as apprentices, and that pattern still remains. Through kinship relations, masters recruit apprentices. After serving an agreed period, the apprentice is given cash, or a specified quantity of trading goods, or both, with which to begin own business. In time, and after establishing the business, the new master will in turn recruit apprentices as assistants primarily from among kin. Thus, kinship links urban business success to labor recruitment from rural home base for Igbo businesses and to manpower training for Igbo society (Chukwuezi, 2001). There is also the

\footnotetext{
${ }^{10}$ We use the phrase "ethnic group" for simplicity. It is meant to designate a religious group or an ethno-religious group (e.g., Yoruba Muslims) too. We also note that we assume two groups for clarity in the exposition. Assuming $n$ groups will not change our results qualitatively.

${ }^{11}$ In this paper, ethnic capital is viewed as competing with human capital for an individual's time endowment. We are therefore not interested in those forms of ethnic capital that instead facilitate the acquisition of human capital. In fact, those forms of ethnic capital could be viewed as human capital too.
} 
issue of Muslim Northerners concentrating on foreign currency exchange businesses across the country. These businesses are so prevalent that Hausa quarters, as their areas of residence are called, in most cities are places where locals go to buy and sell foreign currencies and often those are not registered Bureau De Change. Note that the important distinction between the ethnic labor market and the formal labor market is that the former is accessible only to those from the same ethnic group whereas the latter is accessible without discrimination to all those who invested in human capital.

Let a fraction $h_{i t}$ from ethnic group $i$ invest in human capital and a fraction $1-h_{i t}$ invest in ethnic capital. The benefit from either form of investment is given by the wages earned. The total level of human capital in the economy is denoted by $h_{t}$ :

$$
h_{t}=h_{1 t} c+h_{2 t}(1-c)
$$

The production function for the formal labor market depends on the total level of human capital in the economy and is given by a well-behaved function $f\left(h_{t}\right)$. To keep the model uncluttered, we do not explicitly model capital for this sector. Wages in the formal labor market are equated to the marginal product of labor given by the function $w\left(h_{t}\right)$. The maximum attainable value for $w\left(h_{t}\right)$ is denoted $\bar{w}$, and its minimum attainable value $\underline{w}$. It is assumed that the production function exhibits diminishing marginal returns to scale and that wages are strictly positive. These assumptions are summarized below:

- A1 The wage function, $w\left(h_{t}\right)$, is continuous and strictly decreasing in $h_{t}$. Further, $w(h)>$ 0 for any $h>0$.

The production function for the ethnic labor market of the ethnic group $i$ is given by $g\left(\theta_{i},(1-\right.$ $\left.h_{i t}\right) c_{i}$ ), where $\left(1-h_{i t}\right) c_{i}$ measures the total investment in ethnic capital by the current cohort of the ethnic group and $\theta_{i}$ denotes the assets available to ethnic community $i$ for use in the ethnic production function. The variable $\theta_{i}$ is called the ethnic wealth. Ethnic wealth can be interpreted as actual wealth used in the production of goods and services by the ethnic community, or, more broadly, as including the cultural factors which make the ethnic wage more valuable. The two groups may have different levels of ethnic wealth which indicates different incentives for members of the two groups to invest in ethnic capital. The implied wages for ethnic group $i$ is given by $w_{e}\left(\theta_{i},\left(1-h_{i t}\right) c_{i}\right)$. We again assume that this production function exhibits diminishing marginal returns to scale with respect to the labor input. On the other hand, the ethnic wage is assumed to be increasing in the level of ethnic wealth. These assumptions are summarized below:

- A2 The ethnic wage function, $w_{e}\left(\theta_{i},\left(1-h_{i t}\right) c_{i}\right)$, is continuous in both arguments, strictly increasing in $\theta_{i}$, and strictly decreasing in $\left(1-h_{i t}\right)$.

The relative cost of human capital investment depends on the ability of the individual as well as the size of his ethnic group's older cohort which invested in human capital. ${ }^{12}$ We assume that the

\footnotetext{
${ }^{12}$ Child ability can be proxied by parental ability which is measured by parental wealth and education.
} 
ethnic capital formation costs nothing while the cost of human capital formation is given by $c\left(a, h_{i t-1}\right)$, where $a \in[0,1]$ denotes the ability of the individual and $h_{i t-1}$ denotes the human capital investment by the older cohort of ethnic group $i$. Note that the assumption of ethnic capital formation costs being zero is purely cosmetic since $c\left(a, h_{i t-1}\right)$ is being interpreted as the relative cost of acquiring human capital. We assume that:

- A3 Ability, $a$, is distributed in both groups according to the same distribution function $G(a)$ and this distribution is invertible.

- $\mathbf{A} 4$ The cost function, $c\left(a, h_{i t-1}\right)$, is continuous and decreasing in both its inputs.

Assumption A3 says that the two groups do not differ with regard to the distribution of ability. This assumption ensures that ex-post differences in human capital investment are not driven by differences in ability across ethnic groups and so that attention can be focused on the other actionable drivers of group differences. It is in line with Loury's (2002) axiom of anti-essentialism. Assumption A4 says that the cost of human capital formation is decreasing in both the ability of the individual as well as in the investment in human capital by the older cohort of the individual's ethnic group. This assumption is based on the fact that a child who is helped in his homework by his educated parents or by the older members of his ethnic group learns faster, meaning that the human capital of his parents and ethnic community decreases his cost of learning or of acquiring human capital.

Given the wage functions $w($.$) and w_{e}(.,$.$) and the cost function c(.,$.$) , the economy is described$ by $\mathcal{E}=\left\{c,\left(\theta_{1}, h_{10}\right),\left(\theta_{2}, h_{20}\right)\right\}$. The following lemma then automatically follows from the assumptions.

Lemma 1 Let $\mathcal{E}$ be an economy satisfying assumptions $\boldsymbol{A}$ 1-A4. For each ethnic group $i$ in period $t$, there exists a threshold ability $a_{i t}$ such that all individuals in group $i$ with ability greater than $a_{i t}$ choose to invest in human capital.

The lemma holds because the cost of acquiring human capital is decreasing in ability and the stock of human capital of the older cohort is the same for all members of an ethnic group. If $h_{i t}$ is the equilibrium level of human capital in period $t$ of ethnic group $i$, then it must be that:

$$
a_{i t}=G^{-1}\left(1-h_{i t}\right)
$$

Note that, in equilibrium, $a_{i t}$ (and hence $h_{i t}$ ) depends on the benefit of investing in human versus ethnic capital given by the following function:

$$
b\left(h_{i t}, h_{j t}, \theta_{i}, h_{i t-1}\right)=w\left(h_{i t} c_{i}+h_{j t}\left(1-c_{i}\right)\right)-w_{e}\left(\theta_{i},\left(1-h_{i t}\right) c_{i}\right)-c\left(G^{-1}\left(1-h_{i t}\right), h_{i t-1}\right)
$$

Hence, for any fixed value of human capital investment by ethnic group $j$, say $\overline{h_{j t}}$, it must be that the optimal proportion of ethnic group $i$ that invests in human capital is given by the implicit function 
$h\left(\overline{h_{j t}}, \theta_{i}, h_{i t-1}\right)$ such that:

$$
h\left(\overline{h_{j t}}, \theta_{i}, h_{i t-1}\right)=\left\{\begin{array}{lll}
0 \text { if } & b\left(h_{i t}, \overline{h_{j t}}, \theta_{i}, h_{i t-1}\right) & <0 \forall h_{i t} \in[0,1] \\
h_{i t} \text { if } & b\left(h_{i t}, \overline{h_{j t}}, \theta_{i}, h_{i t-1}\right)=0 \\
1 \text { if } & b\left(h_{i t}, \overline{h_{j t}}, \theta_{i}, h_{i t-1}\right)>0 \forall h_{i} \in[0,1]
\end{array}\right.
$$

It follows that the function $h\left(\overline{h_{j t}}, \theta_{i}, h_{i t-1}\right)$ gives the level of human capital investment at which the differential wage from human capital over wage from ethnic capital equals the cost of human capital investment or it must be that for all values of $h_{i}$, the cost $c\left(G^{-1}\left(1-h_{i t}\right), h_{i t-1}\right)$ is always greater (resp. less) than the wage differential $w\left(h_{t}\right)-w_{e}\left(\theta_{i},\left(1-h_{i t}\right) c_{i}\right)$, in which case it must be that the optimal level of human capital investment is $h_{i t}=0$ (resp. $\left.h_{i t}=1\right)$.

The competitive equilibrium path for any economy $\mathcal{E}$ is given by the pair $\left\{h_{1 t}^{*}, h_{2 t}^{*}\right\}_{t=1}^{\infty}$ such that:

$$
\begin{aligned}
& h_{1 t}^{*}=h\left(h_{2 t}^{*}, \theta_{1}, h_{1 t-1}\right) \\
& h_{2 t}^{*}=h\left(h_{1 t}^{*}, \theta_{2}, h_{2 t-1}\right)
\end{aligned}
$$

A competitive equilibrium path is a steady state if $\left(h_{1 t}^{*}, h_{2 t}^{*}\right)=\left(h_{10}, h_{20}\right)$ for all periods $t$. The steady state levels of human capital are denoted by $\left(h_{1}^{*}, h_{2}^{*}\right)$.

\subsection{Main Results}

\subsubsection{Existence and Multiplicity of Equilibria}

The following result proves the existence of a competitive equilibrium path for any economy $\mathcal{E}$.

Theorem 1 For any economy $\mathcal{E}$, given assumptions $\boldsymbol{A} \mathbf{1}-\boldsymbol{A} 4$, there exists a competitive equilibrium path.

Proof. Given assumptions A1-A4, suppose that at some time $t$ the human capital investment by the older cohort, $\left(h_{1 t-1}, h_{2 t-1}\right)$, is given. Then the theorem says that there must exist $\left(h_{1 t}^{*}, h_{2 t}^{*}\right)$

as defined by Equations 5 and 6 . If the level of human capital investment by group 2 is fixed at $\overline{h_{2 t}}$, let $h\left(\overline{h_{2 t}}, \theta_{1}, h_{1 t-1}\right)$ capture the optimal level of human capital investment by group 1 as defined in Equation 4. Note that:

- $w\left(h_{t}\right)-w_{e}\left(\theta_{1},\left(1-h_{1 t}\right) c_{1}\right)$ is continuous and strictly decreasing in $h_{1 t}$ given a fixed $\overline{h_{2}}$; and

- $c\left(G^{-1}\left(1-h_{1 t}\right), h_{1 t-1}\right)$ is continuous and increasing in $h_{1 t}$.

Hence, there exists a unique $h_{1 t}$ such that Equation 4 is satisfied, which implies that the function $h\left(\overline{h_{2 t}}, \theta_{1}, h_{1 t-1}\right)$ is decreasing and continuous in $\overline{h_{2 t}}$. This is true because as $\overline{h_{2 t}}$ increases, the wage differential $w(h t)-w_{e}\left(\theta_{1},\left(1-h_{1 t}\right) c_{1}\right)$ falls for all $h_{1 t}$ while the cost of human capital acquisition remains unchanged. The continuity of the function $h\left(\overline{h_{2 t}}, \theta_{1}, h_{1 t-1}\right)$ follows from the fact that the assumptions imply that the benefit function given in Equation 3 is continuous in all its arguments. 
Given that group 2 faces a similar situation as group 1 with the same wage and cost functions, let $h\left(\overline{h_{1} t}, \theta_{2}, h_{2 t-1}\right)$ be the function that captures the optimal level of human capital investment by group 2. Since both these functions are continuous and are mappings from a compact, convex set onto itself, by the Brouwer fixed point theorem, an equilibrium given by $\left(h_{1 t}^{*}, h_{2 t}^{*}\right)$ must exist such that Equations 5 and 6 are satisfied.

The next proposition looks at the possibility of multiple steady states. Note that the steady states of an economy are determined based on the variables $c, \theta_{1}$, and $\theta_{2}$. It is shown that even if groups are identical ex-ante, a unique symmetric equilibrium is not guaranteed. In particular, asymmetric equilibria exist where the groups choose very different levels of human capital investment.

Proposition 1 Let $\mathcal{E}$ be an economy where the two groups are ex-ante identical in size and in the level of ethnic wealth. Assume A1-A4. It is possible to have more than one steady state. Moreover, steady state may be asymmetric, where $h_{1}^{*} \neq h_{2}^{*}$.

Proof. We prove by example. Assume that:

- $w\left(h_{t}\right)=3-h_{1 t}-h_{2 t}$. Note that this function is decreasing in the total human capital investment by the two ethnic groups. The minimum wage is 1 and the maximum wage is 3 .

- $w_{e}\left(\theta_{i}, h_{i t}\right)=\theta_{i}-\left(1-h_{i t}\right)^{2}$. The two ethnic groups have the same level of ethnic wealth, and suppose $\theta_{1}=\theta_{2}=2$. The ethnic wage function is then exactly the same for the two groups. Note that this wage is decreasing in investment in ethnic capital, which is $\left(1-h_{i t}\right)$. The minimum ethnic wage is 1 while the maximum is 2 .

- $c\left(a, h_{i t-1}\right)=2-a-\left(h_{i t-1}\right)$. Assume that ability is 1 for all individuals. Then $c\left(a, h_{i t-1}\right)=$ $1-h_{i t-1}$.

Given the above, at a steady state where human capital investment is constant over time, the benefit of human capital investment by each group for a fixed level of human capital investment by the other group is given by the functions:

$$
\begin{aligned}
& b\left(h_{1}, \overline{h_{2}}, \theta_{1}\right)=1-\overline{h_{2}}-2 h_{1}+h_{1}^{2} \\
& b\left(h_{2}, \overline{h_{1}}, \theta_{2}\right)=1-\overline{h_{1}}-2 h_{2}+h_{2}^{2}
\end{aligned}
$$

Using Equations 7 and 8, we can see that there are three possible steady state levels of human capital investment given by $\left(h_{1}^{*}=1, h_{2}^{*}=0\right),\left(h_{1}^{*}=0, h_{2}^{*}=1\right)$ and $\left(h_{1}^{*}=.38, h_{2}^{*}=.38\right)$.

The following proposition says that even when two ethnic groups differ in human capital investment, the difference is more pronounced among their low-ability members.

Proposition 2 Let $\mathcal{E}$ be an economy satisfying assumptions $\boldsymbol{A}$ 1-A4. Every period t, there exists an ability threshold $\zeta_{t}$ such that all individuals in each group $i \in\{1,2\}$ with ability greater than $\zeta_{t}$ choose to invest in human capital. 
Proof. The proof follows directly from Lemma 1. In fact, let $\zeta_{t}=\max \left\{a_{1 t}, a_{2 t}\right\}$. Given that all individuals in each group $i \in\{1,2\}$ with ability greater than $\zeta_{t}$ have ability above the group-specific threshold $a_{i t}$, it immediately follows from Lemma 1 that all such individuals choose to invest in human capital.

It is important to notice that Proposition 2 does not say that $\zeta_{t}$ is smaller than 1 . If $\zeta_{t}$ is equal to 1 , then, even with two ex-ante identical groups, it might be the case that all the members of one group choose human capital and all the members of the other group choose ethnic capital, even if all members have very high ability. But if $\zeta_{t}$ is smaller than 1, then Proposition 2 implies that even if two groups differ in human capital investment, members of both groups with ability greater than $\zeta_{t}$ will all invest in human capital, also implying that the difference only occurs among members whose ability falls below $\zeta_{t}$.

\subsubsection{Impacts of Ethnic Wealth and Older Cohort's Human Capital}

The next result shows that the human capital investment of the older cohort positively affects the human capital investment of the current cohort, holding fixed the level of ethnic wealth.

Proposition 3 Let $\mathcal{E}$ be an economy satisfying assumptions $\boldsymbol{A}$ 1-A4. Assume that the two groups have the same level of ethnic wealth $\left(\theta_{1}=\theta_{2}=\theta\right)$ but differ in the initial level of human capital investment $\left(h_{i 0}<h_{j 0}\right)$. Then any competitive equilibrium path $\left\{h_{1 t}^{*}, h_{2 t}^{*}\right\}_{t=1}^{\infty}$ is such that $h_{i t}^{*} \leq h_{j t}^{*} \forall t$.

Proof. Without loss of generality, suppose that $h_{1 t-1}<h_{2 t-1}$. In this case, it must be that for any given ability level $a, c\left(a, h_{1 t-1}\right)>c\left(a, h_{2 t-1}\right)$. Clearly, for the Equations 5 and 6 to hold, it must be that $h_{1 t}^{*} \leq h_{2 t}^{*}$. Or the group starting with the lower level of human capital must have lower human capital all along an equilibrium path.

The following result shows how the level of ethnic wealth affects human capital investment when all other variables are kept constant across the two groups. It is shown that, for groups with the same level of human capital investment of the older cohort, human capital investment is higher for the group with the lower ethnic wealth.

Proposition 4 Let $\mathcal{E}$ be an economy satisfying assumptions $\boldsymbol{A}$ 1-A4. Assume that the two groups have the same initial level of human capital investment, $h_{i 0}=h_{j 0}$, but differ in the level of ethnic wealth $\left(\theta_{i}<\theta_{j}\right)$. Then along any competitive equilibrium path given by $\left\{h_{1 t}^{*}, h_{2 t}^{*}\right\}_{t=1}^{\infty}$, it must be that $h_{i t}^{*} \geq h_{j t}^{*} \forall t$.

Proof. Suppose, without loss of generality, that $\theta_{1}>\theta_{2}$. In this case, for any given ability level $a$, the cost of human capital acquisition is the same for the two ethnic groups. Since $\theta_{1}>\theta_{2}$, if in any period $t$, both groups are such that the same proportion $h$ of their members invest in human capital, then the wage differential from investing in human capital versus ethnic capital will be greater for group 2. And hence in any time $t$ along a competitive equilibrium path, it must be that group 2 invests more in human capital than group 1 unless group 1 is such that all members of the group invest in human capital. 


\subsubsection{Impact of Ethnic Group Size}

The next result highlights the fact that members of ethnic groups with very little ethnic wealth always choose to invest in human capital. We then study the implications of this result when ethnic wealth is assumed to be proportional to the size of the ethnic group's population. This assumption is plausible in ethnic democracies such as the ones prevailing in African countries, where the political power of a group, and so its ability to extract rents to be shared among its members, is positively affected by its size. We make the following additional assumptions:

- $\mathbf{A 5} w_{e}(0,)=$.0 .

- $\mathbf{A 6} \underline{w}>c(0,0)$.

Assumption A5 ensures that in the case there is no ethnic wealth, the wages from ethnic labor market must be zero. Assumption A6 is equivalent to saying that, in the case where the ethnic wages are zero, then all individuals, including those with the least ability and belonging to a group where no one from the older cohort invested in human capital, prefer to invest in human capital. Hence, when investment in ethnic capital is not a feasible alternative, then the individual always invests in human capital.

Proposition 5 Let $\mathcal{E}$ be an economy satisfying assumptions A1-A6. The following assertions are correct at all times along a competitive equilibrium path:

1. The members of a group with low enough ethnic wealth always choose to invest in human capital.

2. If the ethnic wealth is proportional to the size of the ethnic group, then sufficiently small groups will invest only in human capital.

3. Suppose there are $n$ ethnic groups such that the $i$-th group is of size $c_{i}=\frac{1}{n}$ and its investment in human capital at time $t$ is given by $h_{i t}$. The total human capital is given by $h_{t}=\sum_{i=1}^{n} h_{i t}$. If the ethnic wealth is proportional the size of the ethnic group, then sufficiently increasing the number of ethnic groups leads to all individuals investing in human capital. In other words, ethnic and group fragmentation increases investment in human capital.

Proof. 1) It is claimed that there exists a level of ethnic wealth $\underline{\theta} \geq 0$ such that any individual belonging to an ethnic group $i$ whose wealth is below $\underline{\theta}$ always chooses to invest in human capital. Formally, $\underline{\theta}$ must be such that even when the the older cohort has no human capital and the wage from human capital is the lowest, all the members of the ethnic group choose to invest in human capital:

$$
\underline{w}-w_{e}(\underline{\theta}, 0) \geq c(0,0)
$$

There must exist some such $\underline{\theta}$ because it is known that $w_{e}(.,$.$) is continuously increasing in ethnic$ wealth, $w_{e}(0,)=$.0 , and $\underline{w}>c(0,0)$. 
2) Suppose that the size of ethnic wealth depends on the size of the ethnic group, and in particular suppose that $\theta_{1}=c * \theta$ and $\theta_{2}=(1-c) * \theta$. In this case, if $\underline{c}$ is such that $\underline{c} * \theta=\underline{\theta}$, then it must be that, if the ethnic group's size is less than $\underline{c}$, then all the members of the ethnic group invest in human capital.

3) Suppose that there are $n$ equally sized ethnic groups and that ethnic wealth is proportional to ethnic size: $\theta_{i}=\frac{1}{n} \theta$ where $\theta$ is some fixed constant. If $\bar{n}$ is the number of groups such that $\frac{1}{\bar{n}} \theta \leq \underline{\theta}$, then if the number of groups is greater than $\bar{n}$, then all the members of each group will invest in human capital.

The results stated above intuitively come from the fact that low ethnic wealth implies low wages from ethnic capital, and if these wages are much lower than the least wage possible from investing in human capital, then members of groups with low ethnic wealth will not choose to invest in ethnic capital.

\subsubsection{Allowing for Cross-Ethnic Interactions in Human Capital}

We now modify the model to allow for interactions across ethnic groups. In particular, suppose that all times, each individual's cost of acquiring human capital depends not only on the human capital acquisition by the older cohort of his group, but also on the human capital of the older cohort of the other group. Further, let $\beta$ measure the relative importance of his own ethnic group such that, for an individual from group $i$ with ability $a$ at time $t$, the cost of human capital is $c\left(a, \beta h_{i t-1}+(1-\beta) h_{j t-1}\right)$. Without loss of generality, for the rest of this section, we assume that the two groups are of equal size and in that case, $\beta=0.5$ is a situation of perfect assimilation. However, as $\beta$ approaches 1 , the model reverts to the one without cross-ethnic interactions. Given the above, the interesting cases of $\beta$ are where it is in the range $[.5,1]$ where it varies from perfect assimilation to none. With cross-ethnic interactions, the benefit function capturing the difference between the wage differential and the cost of acquiring human capital must be:

$$
\begin{aligned}
b\left(h_{i t}, h_{j t}, \theta_{i}, \beta h_{i t-1}+(1-\beta) h_{j t-1}\right) & =w\left(h_{t}\right)-w_{e}\left(\theta_{i}, 1-h_{i t}\right) \\
& -c\left(G^{-1}\left(1-h_{i t}\right), \beta h_{i t-1}+(1-\beta) h_{j t-1}\right)
\end{aligned}
$$

Given the benefit function, for any fixed value of human capital investment by ethnic group $j$, say $\overline{h_{j t}}$, it must be that the optimal proportion of ethnic group $i$ that invests in human capital is given by the function $h\left(\overline{h_{j t}}, \theta_{i}, \beta h_{i t-1}+(1-\beta) h_{j t-1}\right)$ as defined in Equation 4. Moreover, using the changed definition of the older cohort human capital, the competitive equilibrium path for any economy $\mathcal{E}$ is given by the pair $\left\{h_{1 t}^{*}, h_{2 t}^{*}\right\}_{t=1}^{\infty}$ such that:

$$
\begin{aligned}
& h_{1 t}^{*}=h\left(h_{2 t}^{*}, \theta_{1}, \beta h_{1 t-1}+(1-\beta) h_{2 t-1}\right) \\
& h_{2 t}^{*}=h\left(h_{1 t}^{*}, \theta_{2}, \beta h_{2 t-1}+(1-\beta) h_{1 t-1}\right)
\end{aligned}
$$

The next proposition delves into the impact of changing $\beta$. It assumes inelastic wages such that 
attention can be focussed on the impact of the segregation parameter, $\beta$. Then it shows that, assuming the competitive equilibrium path is unique, it must be that the difference in the human capital acquired by the two groups is increasing in $\beta$. Or the difference in human capital attainment increases as society becomes more segregated.

Proposition 6 In an economy $\mathcal{E}$ with cross-ethnic interactions, given assumptions $\boldsymbol{A} \mathbf{1}-\boldsymbol{A} 4$, let wages in the formal labor market and in the two ethnic labor markets be inelastic w.r.t. the labor supply in each market. Then at each time along the competitive equilibrium path, the difference in the human capital investment by the ethnic groups is increasing in $\beta$.

Proof. At time $t$, suppose the human capital investment by the older cohort is such that $h_{1 t-1} \geq$ $h_{2 t-1}$. Then the proposition says that there must exist $\left(h_{1 t}^{*}, h_{2 t}^{*}\right)$ as defined by Equations 11 and 12 such that the difference $\left|h_{1 t}^{*}-h_{2 t}^{*}\right|$ is increasing in $\beta$.

Let wages in the formal labor market be fixed and given by $w$. Similarly, let the wages in the ethnic labor market be fixed and given by $w_{e}$ for both ethnic groups. Ethnic group $i$ 's level of investment in human capital will be such that it equalizes the wage gap given by $w-w_{e}$ to the cost of acquiring human capital. Note that the cost of acquiring human capital is such that:

- $c\left(G^{-1}\left(1-h_{1 t}\right), \beta h_{1 t-1}+(1-\beta) h_{2 t-1}\right)$ is continuous and decreasing in $\beta$;

- $c\left(G^{-1}\left(1-h_{2 t}\right), \beta h_{2 t-1}+(1-\beta) h_{1 t-1}\right)$ is continuous and increasing in $\beta$.

Hence, the function $h_{1 t}^{*}$ is increasing in $\beta$. This is true because an increase in $\beta$ leads to an increase in the human capital of the older cohort for members of group 1 . This then leads to a lower cost of human capital at all ability levels. Hence, the level of current human capital, which equates the wage differential to the cost of acquiring human capital, must increase as $\beta$ increases. On the other hand, for group 2, an increase in $\beta$ leads to a decrease in the human capital of the older cohort. Hence following a similar reasoning, $h_{2 t}^{*}$ must decrease as $\beta$ increases. In other words, as $\beta$ increases, so does the gap between the human capital acquisitions by the two groups.

The next proposition shows that even perfect assimilation does not assure that there is no difference in the human capital acquired by the two groups. When $\beta=0.5$, both groups differ only by the level of their ethnic wealth. And hence, the only reason for varying human capital investment must be due to differing levels of ethnic wealth. The following result presents an extension of the results given in Proposition 4. It shows that even for perfectly assimilated groups, human capital investment is higher for the group with the lower ethnic wealth.

Proposition 7 In an economy $\mathcal{E}$ with cross-ethnic interactions, given assumptions $\boldsymbol{A} \mathbf{1}-\boldsymbol{A} \mathbf{4}$, if the two groups are perfectly assimilated $(\beta=.5)$ but the level of ethnic wealth is such that $\theta_{i}<\theta_{j}$, then along any competitive equilibrium path of human capital investment given by $\left\{h_{1 t}^{*}, h_{2 t}^{*}\right\}_{t=1}^{\infty}$, it must be that $h_{i t}^{*} \geq h_{j t}^{*} \forall t$. 
Proof. Without loss of generality, suppose that $\theta_{1}>\theta_{2}$. In this case, since $\beta=.5$, it must be that for any given ability level $a$, the cost of human capital acquisition is the same for the two ethnic groups. Since $\theta_{1}>\theta_{2}$, if both groups were such that at any time $t$, the same proportion $h_{t}$ from each group invests in human capital, then the wage differential from investing in human capital versus ethnic capital would be greater for group 2. And hence on the equilibrium path, it must be that group 2 invests more in human capital than group 1 unless group 1 is such that all its members invest in human capital.

\subsection{Testable Implications}

Our findings in the previous section clearly shows that the demand for human capital by an individual is affected positively by his ability (which we will measure by parental wealth and education) and his group's older cohort's human capital, and negatively by his group's size. We empirically test the following predictions of the model.

T1. Two groups that are ex-ante identical may differ in human capital accumulation (Proposition 1).

T2. If two groups differ in human capital accumulation, this difference mostly occurs among the low-ability members of both groups (Proposition 2).

T3. A person's demand for human capital is positively affected by his group's older cohort's human capital (Proposition 3).

T4. A person's demand for human capital is negatively affected by his group's size (Propositions 4, 5 (item 2), and 7).

T5. Ethnic and group fragmentation positively affects the demand for human capital (item 3 of Proposition 5).

Our first prediction (T1) comes from Proposition 1 showing that asymmetric equilibrium outcomes may emerge out of ex-ante identical initial conditions. The empirical implications of this prediction are profound. One implication is that group differences in human capital do not mean that one group is on average smarter than the other. The other implication is that, in a multivariate regression of human capital on group identity (or group membership), group differences may not disappear after all "imaginable" controls are included.

The second prediction (T2) comes from the fact that high-ability individuals always invest in human capital regardless of their group's characteristics. It follows that, if two groups differ in human accumulation, the difference should be concentrated among their low-ability members. This prediction can be tested by estimating group differences in educational attainment across different levels of parental ability. If the prediction is correct, smaller group differences in educational attainment should be seen among children whose parents have a high level of education or wealth.

Our third prediction (T3) has some implications for the intergenerational transmission of human capital. In the context of Nigeria, it also implies that members of ethnic groups that were historically 
exposed to Christian missionary activity should fare better than those whose ancestors were only exposed to Islam. This is because Christian missionaries introduced formal education, and so ethnic groups that were exposed to missionary activity acquired education earlier, and became more educated than members of groups that were not exposed. Following Proposition 3, this initial difference was transmitted to the following cohort, and so on till the present day.

Applying the fourth prediction (T4) to Nigeria partly tells us why smaller ethnic groups, such as the Igbo, have more human capital than larger groups, such as the Hausa/Fulani/Kanuri. The Hausa/Fulani/Kanuri people are culturally homogeneous, and have served as the main constituency of political leaders from northern Nigeria. Their large size partly explains why 9 of the 15 Heads of State that Nigeria has had since its independence have come from the North. Having been in power for so many years compared to other ethnic groups, they have had the opportunity to extract more rents, increasing their ethnic wealth and decreasing their incentives to invest in human capital.

Prediction (T4) also implies that ethnic groups that are more spatially dispersed invest more in human capital than groups that are more concentrated, even holding ability distribution fixed. In fact, group dispersion leads to smaller subgroups, which leads to a greater demand for human capital.

The fifth testable prediction (T5) directly follows from (T4), as fragmentation results in smaller groups. It implies, for instance, that if an ethnic group is split by religion, their members will invest more in human capital. This might explain why the Yoruba group, which is the religiously most fragmented group, fares better than other ethnic groups at most ages. In the next section, we will test each of these predictions of the model.

\section{The Empirical Test}

We test the predictions of the model using data from Nigeria, where ethnicity and religion have emerged as the two most important dimensions of identity. We do not have any evidence that the specific ethnic groups in the country promote or discourage formal education. However, religion is clearly a factor in the decision of certain individuals to acquire education. In the next section, we briefly document the historical role of Christianity and Islam in the spread of formal and religious education in Nigeria.

\subsection{Religion and Education in Nigeria: A Historical Perspective}

Islam was spread and consolidated in most of what later became northern Nigeria by the Jihad of Uthman Dan Fodio about 1804. Historical records show that the introduction of Islam was accompanied by the spread of its own form of holistic education (Fafunwa (1974), Ajidagba (1998)). Islamic education and Arabic learning were simultaneously taught in schools in the region. As a result of the political and social influence which Islam and Koranic learning conferred on those possessing it, many rulers employed Islamic scholars as administrators and Islamic education was supported by northern Nigerian leaders and Northern Region Ministry of Education. Unlike modern formal schools, Islamic schools operate with an open-ended structure that allows each student to pursue an individual course of study. There is no clear-cut division into primary, secondary and tertiary levels. There is no pro- 
gression from one class to another and from one level to another, with examination barriers erected along the way. There are no age limits or rigid timetable with neatly timed periods for subjects (Umar (2003), Abdurrahman and Canham (1978)). Islamic knowledge is acquired through a masterdisciple relationship sustained by face-to-face oral instructions that transmit spiritual guidance, moral authority, piety and blessing (Mohammed and Khan (1981)).

Despite the perception of great spiritual value, one obvious potential disadvantage of this educational curriculum is its focus on Arabic, which is not the language of literature, instruction and correspondence in Nigeria. Also, the transmission of spiritual and moral values is privileged over the acquisition of other forms of knowledge and skills that are valued in a market economy (Suleiman (1995), Sulaiman (2001), Okoye and Yau (1999)).

Western-type education was widely introduced in Nigeria following the arrival of Wesleyan Christian missionaries at Badagry in 1842. Although literary education in the 4Rs (reading, writing, arithmetic and religion) was predominant, this new missionary education prepared the recipients for new job opportunities, as teachers, church evangelists or pastors, clerks and interpreters. Emphasis was also placed on character training. Most of the missions established primary schools and, initially, little emphasis was given to secondary or tertiary education. But following pressure from influential church members, who were rich merchants and emigrants living in Lagos, the CMS Grammar School was established in 1857 in Lagos.

Western-type education spread more quickly in the south than in the north of Nigeria in part because of the skepticism of the Muslims with regards to the value of an education proposed by Christian missionaries. It is estimated that there were about 25,000 Koranic schools already in existence in northern Nigeria in 1914. Thus, the spread of western-style education met stiff opposition except among the indigenous peoples of the North Central geopolitical zone, where Christian missionaries did succeed in establishing schools, at times in collaboration with Government. Abdulkarim (2010) links the educational orientation of Muslim communities and their reluctance to embrace western-oriented education to the belief that it was not supportive of Islamic education, and possibly actively tried to destroy it. Consequently the phenomenon of educational dualism has been historically entrenched in Nigeria (Umar (2003)).

Several scholars have argued that Koranic schools in northern Nigeria are an alternative to formal education, and in fact represent an institutionalized resistance to it (see, e.g., Winters (1987), Koehl (1983), Urwick (1984)). Bray (1981) identified Kano State, the largest Hausa/Fulani state in Nigeria, as one of the states in which implementation of the 1976-1980 Universal Primary Education scheme encountered the most difficulty, owing to the strength of the "rival" tradition of Koranic education and to the low level of existing enrolment in "western-type" schools. A survey of 1,998 pastoral Fulani reported that about half $(50 \%)$ had Koranic education, forty percent had no education, and only seven percent had either formal or both mainstream and Koranic education (Iro (2007)). In a 1993 nationwide survey, NISER (1997) recorded the widespread of Koranic education among ethnic groups in northern Nigeria generally, and notably among Hausa/Fulani/Kanuri. The data shows that $23.5 \%$ of the Hausa/Fulani/Kanuri children aged 5-24 attended Koranic schools and this proportion 
constitutes $95 \%$ of youth of that age group who attended such schools throughout the country.

Recent changes have given rise to new Islamic schools called the madrasa, some of which offer a modified national public school curriculum. Yet they differ in their fundamental institutional orientation. School administrators actively foster Islamic identity and awareness among students and teachers through congressional prayers, images of the Islamic world, and Islamic dress for females (Umar (2003)). While these features collectively create a distinctly Islamic atmosphere in these schools, it is the curricular emphasis on Arabic and Islamic Studies that really shape their Islamic character and orientation, and differentiate them from both the old Islamic educational institutions and Nigeria's public schools. Among other goals, madrasa curriculum aims to foster Islamic identity and consciousness with competencies in Arabic and Islamic studies to "equip students to orient their lives in accordance with Sharia" (Umar (2003)), whereas the national curriculum aims at "self-realization, better human relationship, individual and national efficiency, effective citizenship, national consciousness, national unity, as well as towards social, cultural, economic, political, scientific and technological progress" (Federal Government of Nigeria (1981)).

It follows that the varying distribution of religious beliefs and attitudes towards "western education" across ethnic groups in Nigeria mostly reflects differences in historical exposure to Christian and Islamic activities in this country. Nunn (2010) provides compelling empirical evidence for the fact that the descendants of people that were exposed to European missionaries in Africa more likely self-identify as Christian today, which shows that Christian beliefs and values were transmitted across generations from parents to children until the present day. The same can be said about the intergenerational diffusion of Islam.

\subsection{Data}

This study utilizes a sample of 30,746 male and female individuals aged 5-24, pooled from the 1999 and 2003 Nigeria Demographic and Health Surveys. They are nationally representative, and were designed to provide representative estimates of population and health indicators for all regions and ethnic groups of the country. They used a two-stage probabilistic sampling technique to select clusters (or neighborhoods) at the first stage and households at the second stage. Clusters were selected from each of the 36 States that the country has, and from the capital city. The surveys used household questionnaires to obtain information on members of a household, housing characteristics including living facilities, household composition, and place and region of residence. The individual questionnaires for males and females provided information on demographic, socioeconomic and cultural characteristics including gender, age, education, marital status, migration status, religion, and ethnicity.

The outcome variable we analyze is the number of years of education acquired. Our main independent variable is ethnicity (or membership in a tribe). The DHS data provide information on 113 ethnic groups. In this study, we borrow from the NISER (1997) classification and aggregate these groups into five major categories: the Hausa/Fulani/Kanuri of the core North, the Igbo of the South East, the Yoruba of the South West, the Isoko/Urhobo/Edo/Ijaw/Efik/Ibibio of the Niger-Delta region and the Tiv/Igala/Idoma/Gwari of the Central region, also known as the Middle-Belt. There 
was a mixture of other groups that do not fit into these core groups. This mixture is labeled in this study as "Other ethnicity". It is important to note that, except for the category "Other ethnicity", these groupings represent the best approximation of distinct cultural identities in Nigeria, mirroring geographical, economic, political and religious enclaves (NISER (1997)). A similar classification is followed in most studies on Nigeria (see, e.g., Osili (2007), Uwaifo (2008)).

In order to explain cross-ethnic differences in educational attainment, we control for a range of individual, household and neighborhood level variables, the details of which are presented in Table 1. These factors are inspired by the vast literature on human capital, and they measure various inputs into education. Their levels are likely to vary across ethnic groups. The individual level variables are child gender, age and relationship to the household head. The inclusion of the latter variable could be explained by the fact that parents may tend to invest more in biological children, but kinship obligations vary across ethnic groups, and some groups may tend to differentiate less between biological and non-biological children. The household level factors controlled for are the characteristics of the household head (gender, age, education and religion), as well as household wealth per capita. ${ }^{13}$ We also control for neighborhood fixed effect, therefore taking into account all community-level variables. We further control for minority status. An individual is in the minority group if he belongs to the minority religion within his ethnic group. The variable for minority status takes the value of 1 if an individual is a Muslim Igbo, Muslim Yoruba, Muslim Niger-Delta, Muslim Middle-Belt, or Christian Hausa/Fulani/Kanuri, and takes the value 0 otherwise.

\subsection{Empirical Results}

\subsubsection{Cross-Ethnic Differences in Educational Attainment: Multiplicity of Equilibria}

We test our first two prediction (T1) regarding cross-ethnic differences in educational attainment. We use ordinary least squares to estimate a regression-based model of the form:

$$
\text { Educ }_{i r}=\text { Ethnicity }_{i} \alpha+X \beta+\mu_{r}+\varepsilon_{i r}
$$

where $E d u c_{i r}$ is the number of years of education attained by a person $i$ living in a neighbordhood $r$, and Ethnicity $i$ a vector of five binary indicators for ethnic groups Hausa/Fulani/Kanuri, Igbo, Niger-Delta, Middle-Belt, and "Other ethnicity". The Yoruba ethnic group is the reference group. $X$ is a vector of variables including individual, household and neighborhood level variables. The term $\mu_{r}$ captures the neighborhood fixed effect, and $\varepsilon_{i r}$ is the individual random effect. The vector of coefficients $\alpha$ represents the main parameters of interest. Because of differential supply of education across neighborhoods and the possible correlation between neighborhood and ethnicity (i.e. $E\left(\mu_{r}\right.$ Ethnicity $\left._{i}\right) \neq 0$ ), we estimate neighborhood fixed effects. This ensures that the supply of education is similar for all individuals living in the same neighborhood. We also control for minority status.

\footnotetext{
${ }^{13}$ Household wealth is an asset-based index. It is constructed based on possession of assets such as the physical quality of the home (materials for roof, wall, and floor), means of personal transportation (bicycle, motorcycle, car), and household durables (radio, TV, video, electricity, piped water, etc.). We construct this index using the principal component analysis (Filmer and Pritchett (2001), Montogomery et al. (2000)). We then divide it by the number of household members.
} 
In fact, the supply of educational institutions being the same for all individuals within a neighborhood might not not ensure that the access is the same for all. Maybe the dominant ethnic group has an advantage in access to schools over the ethnic minorities. This may be especially relevant where (good) schools are in short supply. Controlling for minority status in addition to neighborhood fixed effects ensures that $\alpha$ only estimates differences in the demand for education. Importantly, ethnicity (or tribe), like race, is not a choice variable. Membership in a tribe is by ancestry or by birth. For this reason, ethnicity precedes educational investment, which also implies that it is exogenous with respect to the latter variable. ${ }^{14}$ It follows that all observed and unobserved variables that may be correlated with ethnicity and educational attainment mediate rather than confound the effect of the former variable on the latter. ${ }^{15}$

After controlling for a range of individual, household and neighborhood level characteristics, we argue that the remaining differences in educational attainment across ethnic groups is consistent with prediction (T1) according to which different ex-ante identical ethnic groups may find themselves in different educational equilibria. Consistent with our theoretical analysis, persistent group differences in educational attainment allow to identify ethnic groups that invest more in ethnic capital in equilibrium, as human capital competes with ethnic capital for an individual's time endowment.

The results are presented in Table 2. Standard errors are clustered at the neighborhood level in all of our regression-based analyses. We note substantial differences in educational attainment between ethnic groups. Column (I), which includes only the ethnicity dummies and a binary indicator for the year 2003, shows that Igbo, Niger-Delta, Middle-Belt and Hausa/Fulani/Kanuri children lag behind their Yoruba counterparts by an average of 0.49, 0.42, 1.81 and 4.05 years of education, respectively. In subsequent columns (Columns (II)-(VI)), we control for a range of factors to determine how much of these differences can be explained by the data. Column (II) controls for child characteristics including age and its quadratic term, gender, and relationship with the household head, as well as a dummy indicator for Muslim. We find that the relative disadvantage of Middle-Belt and Hausa/Fulani/Kanuri children over Yoruba children falls, whereas the advantage of the latter over other ethnic groups increases. In results not shown, controlling for child characteristics only do not significantly affect the coefficients found in Column (I), which implies that cross-group differences in educational attainment are not explained by child factors. The changes in the coefficients noted in Column (II) are therefore mainly explained by religion, which also has an independent effect. In this respect, we note that Muslims lag behind Christians by an average of 1.09 years of education.

In Column (III), we additionally control for household characteristics including the household head's age and its quadratic term, gender, education and religion, as well as place of residence and household wealth. Controlling for parental wealth and education (the variables measuring ability or capability in our theoretical model) in particular is consistent with studies that have shown a causal

\footnotetext{
${ }^{14}$ Most studies consider ethnicity and race as exogenous with respect to educational achievement (e.g., Fryer and Levitt (2004)).

${ }^{15}$ In other words, these observed and unobserved factors that are associated with both ethnicity and education do not "cause" ethnicity. Technically, these factors therefore can only be viewed as explaining the association between ethnicity and education.
} 
impact of these variables on child education (see, e.g., Black, Devereux and Salvanes (2005)). The estimates show that the Hausa/Fulani/Kanuri children now lag behind the Yoruba children by only 1.6 years of education. When comparing this coefficient to that of Column (I), we estimate that over $60 \%$ of the education gap between the two groups can be explained by the relative socioeconomic disadvantage of the Hausa/Fulani/Kanuri children and by religious factors. Most of these factors, including parental education, are intergenerational factors. We also note that the relative disadvantage of the Middle-Belt children compared to their Yoruba counterparts decreases by almost 50\%. However, the gap between the Yoruba and the other groups (Igbo, Niger-Delta) continues to grow. In Column (IV), we control for state fixed effects, and the relative advantage of the Yoruba over each of the other ethnic groups decreases, but remains statistically significant.

We now seek to determine whether the remaining differences could be explained by the supply of education, as this might vary across neighborhoods within a state. Since we do not have data on the supply of education, as already noted, we control for neighborhood fixed effects (Column (V)), relying on the assumption that individuals residing within the same neighborhood likely enjoy access to the same educational infrastructure supplied by the federal government, the state or any other organization. We find that the advantage of Yoruba children over their counterparts from other ethnic groups declines in magnitude and statistical significance. Indeed, the Igbo and Niger-Delta children are no longer lagging behind (Column (V)). However, the Middle-Belt and Hausa/Fulani/Kanuri children are still trailing their Yoruba counterparts by 0.65 and 0.96 years of education, respectively.

Although the supply of educational infrastructure is the same for all individuals within a neighborhood, as mentioned earlier, the dominant ethnic group might have an advantage in access to schools. For this reason, in Column (VI), we control for minority status. The relative disadvantage of the Middle-Belt increases, but that of the Hausa/Fulani/Kanuri decreases, but remains statistically significant. That these groups continue to lag behind after controlling for neighborhood fixed effect, minority status, and a wide range of individidual and household variables strongly suggests that a lower demand for (rather than a limited supply of) education explains their poor performance.

The cost of formal education might prevent members of certain groups from enrolling in school. To address this issue, we exploit the fact that enrollment in public primary schools was declared free in Nigeria in 1999. This measure most likely impacted younger individuals. We therefore estimate the effect of ethnicity on education for distinct age groups. In Table 3, we replicate the analysis of Table 2 for four separate age groups: 5-9 years old, 10-14 years old, 15-19 years old, and 20-24 years old. For each age group, Column (I) controls only for ethnicity, and Column (II) controls for all the variables in Column (V) of Table 2. Qualitatively, the findings do not differ much from those obtained in Table 2. In all age groups, the advantage of Yoruba children over the Igbo and the Niger-Delta disappears when all variables are controlled for (Columns (II)). Furthermore, the relative disadvantage of the MiddleBelt children is only visible among the 10-14 and the 20-24 year olds. However, Hausa/Fulani/Kanuri children consistently lag behind, with their distance to the Yoruba increasing with age.

We now seek to determine the level of education at which differences in educational attainment across ethnic groups are more salient. We re-estimate equation (E1) separately for primary, secondary 
and tertiary education as dependent variables. The results are shown in Table 4 . For each outcome variable, Column (I) only controls for ethnicity, and Column (II) controls for all the variables controlled in Column (V) of Table 2 including neighborhood fixed effects. We find that, in general, the Middle-Belt and the Hausa/Fulani/Kanuri individuals lag behind their Yoruba counterparts at all levels of education, confirming our results in Tables 2 and 3. The probability of having a primary education is about 23 percentage points smaller for the Hausa/Fulani/Kanuri compared to the Yoruba. This difference falls to 7 percentage points when all factors are controlled for. The probability of having a secondary education is about 12 and 30 percentage points smaller for the Middle-Belt and the Hausa/Fulani/Kanuri compared to the Yoruba, but these differences fall after all the other factors are controlled for. The Hausa/Fulani/Kanuri and the Middle-Belt individuals continue to lag behind the Yoruba at the tertiary level, but the relative disadvantage of the Hausa/Fulani/Kanuri becomes statistically insignificant after controlling for other variables (this might be due to the fact that the number of Hausa/Fulani/Kanuri individuals who have a university education is extremely small, representing less than 0.6 percent of all the individuals aged 5-24 from this ethnic group).

Overall, the results validate prediction (T1) on the possibility of there being multiple equilibria, with the Yoruba, the Igbo, the Niger-Delta, and to a certain extent the Middle-Belt being in a different equilibrium compared to the Hausa/Fulani/Kanuri. The diverging outcome of the Hausa/Fulani/Kanuri is consistent with the existence of an equilibrium in which certain individuals in that group invest only in ethnic capital. Indeed, as argued in the introduction, Figure 4 supports this view, as it shows that among the Hausa/Fulani/Kanuri, 23.5\% of children have only a Koranic education, in stark constrast to the Igbo $(0.1 \%)$, the Niger-Delta $(0.4 \%)$, the Middle-Belt $(2.7 \%)$, and the Yoruba $(0.4 \%) .{ }^{16}$

\subsubsection{Cross-Ethnic Differences in Educational Attainment are Mostly Concentrated in Individuals of Low Ability}

In this section, we test prediction (T2) according to which cross-ethnic differences in educational attainment should be more pronounced among low-ability individuals due to the fact that individuals of high ability choose human capital over ethnic capital, regardless of the degree of adherence of their group to oppositional norms.

As already mentioned, we measure an individual's ability by the education of his household's head and by his household's wealth. The results are presented in Tables 5 and 6 . In Panel A of Table 5 , we regress education on ethnicity controlling for all relevant factors (including neighborhood fixed effects) as in Column (V) of Table 2. In Column (I), we estimate this regression over the entire sample, but in subsequent columns, the analysis is restricted to individuals whose parents have no education (Column (II)), primary education (Column (III)), secondary education (Column (IV)), or university education

\footnotetext{
${ }^{16}$ It is interesting to notice that so few Yoruba children invest exclusively in Koranic education in spite of the fact that about half of them are Muslim. In general, we know that members of all groups invest in ethnic capital (for instance, by attending weekly ethnic meetings and events). However, for all the groups except the Hausa/Fulani/Kanuri, most of these events rarely compete with human capital investment for an individual's time endowment, as they are generally organized during the weekend, that is outside of school hours.
} 
(Column (V)). We effectively find that cross-ethnic differences in years of education attained are concentrated among children of low parental education. For instance, Hausa/Fulani/Kanuri individuals lag behind their Yoruba counterparts by 1.7 years of education when parents have no education, and by only 0.4 years of education when parents have a university education, with the latter effect being statistically insignificant. In general, cross-ethnic differences in educational attainment become economically smaller and in most cases lose their statistical significance as parental education increases.

In Panel B, we replicate the analysis shown in Panel A for Muslim individuals only. This restriction controls for common factors inherent in Islam, but at the same time, it allows for the fact that adherence to Islamic norms and traditions may vary across ethnic groups in Nigeria. In general, we find no significant cross-ethnic differences in years of education attained for individuals whose parents have at least a primary level education (the significant advantage of Igbo children born to parents with a university education over their Yoruba counterparts is an exception). Cross-ethnic differences in educational attainment are mostly pronounced among individuals whose parents have no education.

In Panel A of Table 6, we estimate cross-ethnic differences in educational attainment across quintiles of household wealth. We find economically significant differences mostly among poor children (those whose households fall in the first and second wealth quintiles), and these differences decrease as household wealth increases. When we replicate this analysis for Muslim individuals only (Panel B), the results are even stronger. ${ }^{17}$

In general, our findings validate the prediction of the model that cross-ethnic differences in educational attainment are smaller among individuals of higher ability, as these individuals more likely choose human capital over ethnic capital regardless of their ethnic groups's adherence to oppositional norms. The findings are not driven by the differential supply of formal education across ethnic groups, as we control for neighborhood fixed effects. The results clearly suggest that among the Hausa/Fulani/Kanuri, it is the low-ability children that invest only in Koranic education, whereas children of comparable ability in other ethnic groups invest in formal education, clearly validating (T2).

\subsubsection{Group's Older Cohort's Human Capital Positively Affects the Demand for Formal Education Regardless of Parental Ability}

In this section, we test prediction (T3) that an individual's demand for human capital is positively affected by his ethnic group's older cohort's human capital regardless of the ability of his parents. We measure the older cohort's human capital in an ethnic group by the proportion of adults (at least 25 years old) with at least a secondary or university level education in that group. As our observation units are individuals aged 5-24 years, using the education of individuals aged at least 25 years to test (T3) guarantees a certain degree of exogeneity of our predictor. It also allows us to avoid the reflection

\footnotetext{
${ }^{17}$ We observe that there are no Muslim Igbo in the 1st, 2nd and 3rd wealth quintiles. The fact that Muslim Igbo belong only to the richest quintiles is evidence supporting the proposition that when a distinct group is small in size, its members tend to do better than when they belong to a large group, perhaps knowing ab-initio that their only abilities will determine whether they succeed or perish as they will have little or no significant amount of the social capital which plays a crucial role in determining outcomes in a patronage-based society like Nigeria.
} 
problem, as children do not influence the educational choices of adults, it is rather the contrary.

We estimate the following equation:

$$
\text { Educ }_{i r}=\text { GroupAbility }_{i r} \alpha_{1}+\text { GroupAbility }_{-i r} \alpha_{2}+\text { ability }_{i} \alpha_{3}+X \beta+\mu_{r}+\varepsilon_{i r}
$$

where GroupAbility ir $_{\text {is }}$ the older cohort's human capital in the ethnic group of individual $i$ in neighborhood $r$; GroupAbility-ir is a vector of variables, each of which represents the older cohort's human capital in an ethnic group (to which $i$ does not belong) in neighborhood $r$; ability is the ability of individual $i$ 's parents (measured by education and wealth); and $X$ a range of other individual, household, and neighborhood characteristics. We estimate Equation (E2) using the entire sample first, and then the subsample representing each ethnic group.

Our first set of results is presented in Table 7. In each Column (I), we include our main predictor and control for seven dichotomous indicators for the year 2003 and for whether an ethnic group is represented in a neighborhood. In each Column (II), we additionally control for parental education and wealth and other relevant factors as listed in Column (IV) of Table 2.

When estimates are based on the entire sample, we find that the proportion of educated Igbo and Hausa/Fulani/Kanuri adult individuals increases children's education in general, while the proportion of educated Yoruba, Niger-Delta and Middle-Belt individuals has the opposite effect when all controls are included. We now restrict the analysis to each ethnic group. In general, the share of educated adults in an ethnic group has its largest positive effect on the education of children belonging to that ethnic group, and in some cases has a negative effect on other ethnic groups. For instance, a onepoint increase in the share of educated Yoruba adults increases the education of Yoruba children by 1.7 years (Column (I)) and that of Hausa/Fulani/Kanuri children by 0.6 years, but has a negative and statistically insignificant effect on Igbo children. Similarly, a one-point increase in the share of educated Igbo adults increases education among the Igbo children by 3 years (Column (I)), but decreases education among the Hausa/Fulani/Kanuri children by 2.2 years, and has no effect on other ethnic groups. Likewise, a one-point increase in the share of educated Hausa/Fulani/Kanuri adults increases education by 5.2 years among Hausa/Fulani/Kanuri children, but has little effect on other children. When controls are introduced (Column (II)), these effects diminish, but do not qualitatively change the results.

The results do not change qualitatively if we measure the older cohort's human capital by the share of adults with a university level education (Table 8). We still see a strong network effect according to which the proportion of educated adult individuals in a group positively affects educational attainment in that group mostly.

In general, the findings validate prediction (T3) of the model that an individual who belongs to an ethnic group with a large proportion of educated older cohort is more likely to choose human capital over ethnic capital regardless of the ability of his parents. Interestingly, we note that these effects are mostly confined within ethnic groups, as the proportion of educated adults in a given ethnic group has little impact on children belonging to other ethnic groups in general. This result also provides 
evidence for the fact that ethnic groups in Nigeria are not "mutually" integrated. ${ }^{18}$

\subsubsection{Minority Status and Educational Attainment}

In this section and the next section, we test prediction (T4) that being in a smaller ethnic group increases the demand for human capital. We regress educational attainment on a binary indicator for being a minority individual and interaction terms between this latter variable and ethnicity. The results are presented in Table 9. In Column (I), we only control for minority status, and find that being a minority individual is associated with over 0.9 more years of education. In Column (II), we additionally control for ethnicity and all the other variables as in Column (V) of Table 2. The effect of minority decreases but remains economically and statistically significant. In Column (III), we control for the interaction terms between minority status and ethnicity. We find that the coefficients on those terms are positive but not statistically significant (except the interaction with the Middle-Belt).

We also note that the interaction term between minority status and the category "other ethnicity" is removed because this category is treated as a majority group. In Table 10, we treat this category as a minority group, and so we generate a different variable for minority status which incorporates this change. We replicate the analysis in Columns (I)-(III), which yields the results in Columns (IV)-(VI), respectively. The findings are qualitatively the same as those found in Columns (I)-(III). These results clearly show that minorities invest more in human capital than majorities, which validates Prediction (T4).

\subsubsection{Smaller Group Size and Ethnic Fragmentation have Positive Effects on Formal Education Demand}

The second way to test prediction (T4) is to estimate the effect of an individual's group size in a neighborhood on his educational attainment. As we have shown theoretically, a corollary of (T4) is that local ethnic fragmentation should have a positive effect on the demand for formal education, which is prediction (T5). To test these two predictions, we estimate the following equation:

$$
\text { Educ }_{\text {irs }}=\text { GroupSize }_{i r} \alpha_{1}+E L F_{r} \alpha_{2}+\text { ethnicity }_{i} \alpha_{3}+X \beta+\mu_{s}+\varepsilon_{i r s}
$$

where GroupSize $e_{i r}$ is the relative population share of individual $i$ 's ethnic group in neighborhood $r$; $E L F_{r}$ is the Hirschman-Herfindahl index of ethno-linguistic fragmentation in neighborhood $r^{19}$; and $\mu_{s}$ is the state fixed effect. ${ }^{20}$ We also control for ethnicity, and all the child, household and neighborhood

\footnotetext{
${ }^{18}$ There is an exception. Table 7 , but not Table 8 , shows that the proportion of educated adults in the category "other ethnicity" positively affects the educational attainment of children belonging to the other ethnic groups (except the Middle-Belt), but the adults from these latter groups do not have a similar effect on children in the category "other ethnicity", which suggests a one-way integration.

${ }^{19}$ Let $P=\left\{E_{1}, \ldots, E_{C}\right\}$ be the collection of ethnic groups in a neighborhood $r$. Denoting the size of an ethnic group $E_{c}$ by $n_{c}$, the Hirschman-Herfindahl index of ethnic fragmentation for that neighborhood is given by:

$E L F_{r}=1-\sum_{1 \leq c \leq C} \frac{n_{c}^{2}}{\left(n_{1}+\ldots+n_{C}\right)^{2}}$

${ }^{20}$ Nigeria has 36 states plus the capital city which is sampled separately, and each state, like the capital city, can be viewed as a collection of neighborhoods. We control for state fixed effects (instead of neighborhood fixed effects) because $E L F_{r}$ varies at the neighborhood level, and so controlling for neighborhood fixed effects would not allow us to estimate the effect of $E L F_{r}$.
} 
characteristics included in Column (IV) of Table 2. These variables are included incrementally.

The findings are presented in Table 10. A one-point increase in the relative size of an individual's ethnic group decreases his educational attainment by 1.5 years if other variables are not controlled for (Column (I)), by 1.2 years if we control for ethnicity (Column (II)), and by 0.2 years if we additionally control for child and household characteristics (Column (III)) and state fixed effects (Column (IV)). All these effects are all statistically significant, clearly validating (T4).

Finally, we test prediction (T5) that local ethnic fragmentation has a positive effect on the demand for education. In Columns (V)-(VIII), we replicate the analysis in Columns (I)-(IV), now replacing the relative size of one's ethnic group by the index of ethno-linguistic fractionalization computed at the neighborhood level. We find that a one-point increase in that index increases individual education by 2.3 years when no other control is included (Column $(\mathrm{V})$ ), and by 0.5 years when all the controls are included (Column (VIII)). These effects are all statistically significant.

Importantly, in Column (IX), we simultaneously control for the neighborhood share of one's ethnic group and ethnic fragmentation, along with all the other variables in Columns (IV) and (VIII). We now find that only ethnic fragmentation has a statistically significant effect, which simply implies, consistent with the theory, that the fact that ethnic fragmentation has a positive effect on the demand for education in Columns (V)-(VIII) is a corollary of the positive effect that being in a smaller group has on this outcome.

\section{Conclusion}

We studied the causes of ethnic inequality in human capital investment. Ethnic groups are exogenous, but adherence to group values is endogenous, as is the decision to invest in human capital. We uncovered important individual- and group-level determinants of educational attainment. An individual's demand for human capital is affected positively by the ability of his parents and his group's older cohort's human capital, and negatively by the size of his group. The findings also imply that asymmetric equilibrium outcomes may emerge out of identical initial conditions. Particularly, even if the distribution of ability is identical across all ethnic groups, these groups may still differ in average educational attainment in equilibrium, with the difference mostly occurring among individuals of sufficiently low ability, as hgh-ability individuals mostly invest in human capital. Moreover, the results show that ethnic and group fragmentation increases the "demand" for human capital. The mechanism is that fragmentation leads to smaller groups, and members of small enough groups invest more in human capital as they generate little benefits from ethnic capital.

We validate all these predictions of the model using nationally representative household data from Nigeria where tribal affiliation and religion are the primary sources of cultural identification. In particular, we document huge ethnic and religious differences in educational attainment, and explain these differences by the fact that low-ability members of historically Muslim groups (i.e. Hausa/Fulani/Kanuri) choose Koranic education as an alternative to formal education. These findings also demonstrate the long-lasting impacts of differential historical exposure to Christianity and Islam on contemporary dif- 
ferences in educational attainment between ethnic groups in Nigeria. We do not argue that individuals in the worst-off groups are intrinsically of lower ability as compared to other individuals. Such a claim would probably be wrong and completely misleading. As shown theoretically, identical groups might achieve different outcomes.

The demonstrated positive effect of group fragmentation on the demand for human capital might explain the highest success of the Yoruba, the most religiously fragmented group. The outcomes for Yoruba Muslims also offer a compelling illustration of the fact that an individual may belong to a social group without necessarily adhering to its core values when these are in opposition to mainstream values. Indeed, despite being $46 \%$ Muslim, only $0.4 \%$ of the Yoruba attend exclusively Koranic schools. In general, we emprically validate the theoretical prediction that members of smaller groups invest more in human capital. This also explains why despite the fact that Muslims lag behind Christians in general, their disadvantage is only apparent in ethnic groups in which they represent a fairly large share.

Our theoretical findings also answer a puzzle raised by John Ogbu (1978) who, reflecting on the educational attainment of African Americans, sought to understand why groups of people of the same ancestry but located in different regions or countries demonstrated different educational achievement. He argued that Black Americans could be partitioned into "voluntary minorities" and "involuntary minorities" (descendants of Blacks who came to the United States through slavery), and that the latter tended to adopt an oppositional attitude towards mainstream culture, including formal education. No such partition of minorities can be achieved in most countries. Yet, our findings show that members of the same ethnic group who are located in different regions of a country are likely to differ with respect to how they accumulate human capital, simply because smaller subgroups perform better than larger subgroups. This may explain why second and subsequent generation migrants whose parents have left their region of origin to settle in another region within a country generally do better than their co-ethnics who remain in their homeland. This will be the case even if the distribution of ability does not differ across the group that left and the one that did not. 


\section{References}

Abdulkarim, S.B. (2010): "Islamiyya Schools and the Development of Qur'anic Education in Nigeria," http://www.arewahouseabung.org/Siraj.pdf. (Access on 30/04/2010).

Abdurrahman, A. M., and P. Canham (1978): The Ink of the Scholar: The Islamic Tradition in Nigeria, Lagos: Macmillan.

Acemoglu, D. (2009): Introduction to Modern Economic Growth. Princeton University Press. Ainsworth-Darnell, J. W., and D. B. Downey (1998): "Assessing the Oppositional Culture Explanation for Racial/Ethnic Differences in School Performance," American Sociological Review, 63(4), 536-553.

Ajidagba, U. A. (1998): "An Onverview of Islamic Education System in Nigeria," Journal of Curriculum and Instruction, 5(1-2): 87-96.

Akerlof, G. A. (1980): "A Theory of Social Custom, of Which Unemployment May be One Consequence," Quarterly Journal of Economics, 94(4), 749-775.

Akerlof, G. A. (1997): "Social Distance and Social Decisions," Econometrica, 65(5), 1005-1028.

Akerlof, G. A., and R. E. Kranton (2000): "Economics And Identity," Quarterly Journal of Economics, 115(3), 715-753.

Almond, D., and J. Currie (2011): "Human Capital Development before Age Five," In Handbook of Labor Economics, Vol. 4, Part B, ed. Orley Ashenfelter and David Card, North Holland, Amsterdam.

Alesina, A., R. Baqir, and W. Easterly (1999): "Public Goods and Ethnic Divisions," Quarterly Journal of Economics, 114(4), 1243-1284.

Alesina, A., and E.L. Ferrara (2005): "Ethnic Diversity and Economic Performance," Journal of Economic Literature, 43(3), 762-800.

Arrow, K.J. (1973): "The Theory of Discrimination," In Discrimination in Labor Markets, edited by O. Ashenfelter and A. Rees. Princeton University Press.

Austen-Smith, D., and R. G. Fryer (2005): "An Economic Analysis of "Acting White"," Quarterly Journal of Economics, 120(2), 551-583.

Banerjee, A.V. (1992): "A Simple Model of Herd Behavior," Quarterly Journal of Economics, 107(3), 797-817.

Barro, R. J., and R. M. McCleary (2003): "Religion and Economic Growth across Countries," American Sociological Review, 68, 760-781.

Barro, R. J., and R. M. McCleary (2005): "Which Countries Have State Religions?" Quarterly Journal of Economics, 120, 1331-1370.

Becker, G.S (1957): The Economics of Discrimination. University of Chicago Press.

Becker, G.S. (1962): "Investment in human capital: A theoretical analysis," Journal of Political Economy, 70, 9-49.

Becker, G.S. (1964): Human Capital. New York: Columbia University Press.

Becker, G. (1997): "Replication and Reanalysis of Offenbacher's School Enrollment Study: Implications for the Weber and Merton Theses," Journal of the Scientific Study of Religion, 
$36,483-495$.

Becker, S., and L. Woessmann (2009): "Was Weber Wrong? A Human Capital Theory of Protestant Economic History," Quarterly Journal of Economics, 124(2), 531-96.

Belhaj and Deroian (2011): "Competing activities in social networks," Mimeo.

Benabou, R. (1996): "Equity and Efficiency in Human Capital Investment: The Local Connection," Review of Economic Studies, 63, 237-264.

Bernheim, B. D. (1994): "A Theory of Conformity," Journal of Political Economy, 102(5), 841-877.

Bisin, A., E. Patacchini, T. Verdier, and Y. Zenou (2010): "Bend It Like Beckham: Ethnic Identity and Integration," CReAM Discussion Paper Series 1025.

Bisin, A., and T. Verdier (2000): "Beyond the Melting Pot: Cultural Transmission, Marriage, and the Evolution of Ethnic and Religious Traits," Quarterly Journal of Economics, 115(3), 955-988.

Black, S.E., P.J. Devereux, and K.G. Salvanes (2005): "Why the Apple Doesn't Fall Far: Understanding Intergenerational Transmission of Human Capital," American Economic Review, 95(1), 437-449.

Blum, U., and L. Dudley (2001): "Religion and Economic Growth: Was Weber Right?" Journal of Evolutionary Economics, 11, 207-230.

Bodenhorn, H., and C. S. Ruebeck (2003): "The Economics of Identity and the Endogeneity of Race," NBER Working Papers 9962, National Bureau of Economic Research, Inc.

Bowles, S., G.C. Loury, and R. Sethi (2014): "Group Inequality," Journal of the European Economic Association, 12(1), 129-152.

Borjas, G. J. (1992): "Ethnic Capital and Intergenerational Mobility," Quarterly Journal of Economics, 107(1), 123-150.

Bray, M. (1981): Universal Primary education in Nigeria: A study of Kano State, London: Henley, and Boston: Routeledge and Kegan Paul.

Calvó-Armengol, A., and M.O. Jackson (2004): "The Effects of Social Networks on Employment and Inequality," American Economic Review, 94(3), 426-454.

Calvó-Armengol, A., and M.O. Jackson (2005): "Networks in Labor Markets: Wage and Employment Dynamics and Inequality," Journal of Economic Theory, 132, 27-46.

Calvó-Armengol, A., E. Pattachini, and Y. Zenou (2009): "Peer Effects and Social Networks in Education," Review of Economic Studies, 76(4), 1239-1267.

Case, A., D. Lubotsky, and C. Paxson (2002): "Economic Status and Health in Childhood: The Origins of the Gradient", American Economic Review, 92(5), 1308-1334.

Chang, S. M., S. P. Walker, S. Grantham-McGregor, and C. A. Powell (2002): "Early Childhood Stunting and Later Behaviour and School Achievement," Journal of Child Psychology and Psychiatry, 43(6), 775-783.

Chukwuezi, B. (2001): "Through Thick and Thin: Igbo Rural-Urban Circularity, Identity and Investment," Journal of Contemporary African Studies 19(1), 55-66. 
Constant, A.F., and K.F. Zimmermann (2008): "Measuring Ethnic Identity and its Impact on Economic Behavior," Journal of the European Economic Association, 6, 424-433.

Costa, D.L., and M.E. Kahn (2003): "Civic Engagement and Community Heterogeneity: An Economist's Perspective," Perspective on Politics, 1(1), 103-111

Currarini, S., M. O. Jackson, and P. Pin (2008): "An Economic Model of Friendship: Homophily, Minorities and Segregation," Econometrica, 77(4), 1003-1045.

Currie, J. (2000): "Child Health in Developed Countries," in The Handbook of Health Economics, J. P. Newhouse and A. J. Culyer (eds.). Amsterdam: North Holland.

Currie, J., and E. Moretti (2003): "Mother's Education and the Intergenerational Transmission of Human Capital. Evidence from College Openings," Quarterly Journal of Economics, 118(4): 1495-1532.

Currie, J., and M. Stabile (2006): "Child Mental Health and Human Capital Accumulation: The Case of ADHD," The Journal of Health Economics, 25(6), 1094-1118.

Currie, J. (2009): "Healthy, Wealthy, and Wise? Socioeconmic Status, Poor Health in Childhood, and Human Capital Devleopment," Journal of Economic Literature, 47(1), 87-122.

Currie, J., M. Stabile, P. Manivong, and L. L. Roos (2010): "Child Health and Young Adult Outcomes," Journal of Human Resources, 45(3), 517-548.

Durlauf, S.N. (1996): "ATheory of Persistent Income Inequality," Journal of Economic Growth, 1, 75-93.

Easterly, W., and R. Levine (1997): "Africa's Growth Tragedy: Policies and Ethnic Divisions" Quarterly Journal of Economics, 112(4), 1203-1250.

Ellison, S. F., and W. P. Mullin (2014): "Diversity, Social Goods Provision, and Performance in the Firm," Journal of Economics and Management Strategy, 23 (2), 465-481.

Esteban, J., and D. Ray (2011): "Linking Conflict to Inequality and Polarization", American Economic Review 101(4), 1345-1374.

Fafchamps, M. (2010): "Ethnicity and Networks in African Trade", Contributions in Economic Analysis \& Policy 2.1.

Fafunwa, A. B. (1974): History of education in Nigeria, London: George Allan.

Federal Republic of Nigeria. (1981): National Policy of Education, Lagos: Government Printer, revised edition.

Fershtman, C., and Y. Weiss (1998): "Social Rewards, Externalities and Stable Preferences," Journal of Public Economics, 70 (1), 53-73.

Fernandez, R., and G. Levy (2008): "Diversity and Redistribution." Journal of Public Economics 92 (5-6), 925-43.

Fordham, S., and J. Ogbu (1986): "Black Students' School Success: Coping with the Burden of Acting White," Urban Review, 18(3), 176-206.

Fryer, R. G., S. D. Levitt (2004): "Understanding the Black-White Test Score Gap in the First Two Years of School," Review of Economics and Statistics 86 (2), 447-464. 
Fryer, R. G., and P. Torelli (2005): "An Empirical Analysis of Acting White," Journal of Public Economics, 94 (5-6), 380-396.

Galor, O., and D.N. Weil (2000): "Population, Technology, and Growth: From Malthusian Stagnation to the Demographic Transition and beyond," American Economic Review, 90(4), 806-828.

Glaeser, E. L., and S. Glendon (1998): "Incentives, Predestination and Free Will," Economic Inquiry, 36, 429-443.

Glaeser, E. L., and B. I. Sacerdote (2008): "Education and Religion," Journal of Human Capital, $2,188-215$.

Glaeser, E. L., and J. Scheinkman (2000): "Non-Market Interactions," NBER Working Papers 8053, National Bureau of Economic Research, Inc.

Glewwe, P. (1999): "Why Does Mother's Schooling Raise Child Health in Developing Countries? Evidence from Morocco," Journal of Human Resources, 34, 124-159.

Glewwe, P., and H. Jacoby (1993): "Delayed Primary School Enrollment and Childhood Malnutrition in Ghana, An Economic Analysis," Living Standards Measurement Study. Working Paper No. 98. World Bank, Washington, D.C.

Goldin, C., and L. F. Katz (2000): "Education and Income in the Early Twentieth Century: Evidence from the Prairies," Journal of Economic History, 60, 782-818.

Granovetter, M. (1973): "The Strength of Weak Ties," American Journal of Sociology, 78(6), 1360-1380.

Granovetter, M. (1995): Getting a Job: A Study of Contacts and Careers, 2nd ed. Chicago: University of Chicago Press.

Guiso, L., P. Sapienza, and L. Zingales (2003): "People's Opium? Religion and Economic Attitudes," Journal of Monetary Economics, 50, 225-282.

Guiso, L., P. Sapienza, and L. Zingales (2006): "Does Culture Affect Economic Outcomes?" Journal of Economic Perspectives, 20, 23-48.

Guiso, L., P. Sapienza, and L. Zingales (2008): "Long-Term Persistence," Chicago GSB Research Paper, No. 08-11.

Huillery, E. (2009): "History Matters: The Long-Term Impact of Colonial Public Investments in French West Africa," American Economic Journal: Applied Microeconomics, 1(2), 176-215.

Iro, I. (2007): "Nomadic Education and Education for Nomadic Fulani," http://www.gamji.com/fulani7.htm (accessed 2007-01-18).

Kandel, E., and E. P. Lazear (1992): "Peer Pressure and Partnerships," Journal of Political Economy, 100(4), 801-817.

Kandori, M. (1992): "Social Norms and Community Enforcement," Review of Economic Studies, $59(1), 63-80$.

Koehl, R. (1983): "Universal Primary Education in Nigeria: A study of Kano State by Mark Bray," International Journal of African Historical Studies, 16(3), 490-492.

Løken, K.V., M. Mogstad, and M. Wiswall (2012): "What Linear Estimators Miss: Re-Examining 
the Effects of Family Income on Child Outcomes," American Economic Journal: Applied Economics, 4, 1-35.

Loury, G.C. (1977): "A Dynamic Theory of Racial Income Differences," In Women, Minorities and Employment Discrimination, edited by P. Wallace and A. LaMond. Lexington Books.

Loury, G.C. (2002). The Anatomy of Racial Inequality. Harvard University Press.

Luke, N., and K. Munshi (2011): "Women as Agents of Change: Female Income and Mobility in India," Journal of Development Economics, 94(1), 1-17.

Lundberg, S., and R. Startz (1998): "On the Persistence of Racial Inequality." Journal of Labor Economics, 16, 292-23.

Lundborg, P., A. Nilsson, and D. Rooth (2012): "Parental Education and Offspring Outcomes: Evidence from the Swedish Compulsory Schooling Reform," IZA DP No. 6570.

Miguel, E., and M.K. Gugerty (2005): "Ethnic Diversity, Social Sanctions, and Public Goods in Kenya," Journal of Public Economics, 89(11-12), 2325-2368.

Mincer, J. (1974): Schooling, experience, and earnings. New York: Columbia University Press for NBER.

Mitra, A., and D. Ray (2014): "Implications of an Economic Theory of Conflict: Hindu-Muslim Violence in India," Journal of Political Economy, 122(4), 719-765.

Mohammed, A. and M.B. Khan. (1981): "From Cradle to Grave: The Contribution of the Ulama to Education in Nigeria," Kano Studies, new series 2(2), 110-128.

Mookherjee, D., S. Napel, and D. Ray (2010a): "Aspirations, Segregation and Occupational Choice," Journal of the European Economic Association, 8, 139-168.

Montgomery, J. (1991): "Social Networks and Labor-Market Outcomes: Toward an Economic Analysis," American Economic Review, 81, 1408-1418.

Montgomery, M., M. Gragnolati, K. Burke, and E. Paredes (2000): "Measuring Living Standards with Proxy Variables," Demography, 37(2), 155-174.

Munshi, K., and M. Rozenweig (2006): "Traditional Institutions Meet the Modern World: Caste, Gender, and Schooling Choice in a Globalizing Economy," American Economic Review, 96(4), 1225-1252.

Munshi, K., and N. Wilson (2010): "Identity and Mobility: Historical Fractionalization, Parochial Institutions, and Occupational Choice in the American Midwest," Department of Economics Working Papers 2010-22, Department of Economics, Williams College.

NISER (Nigeria Institute for Social and Economic Research) (1997): Nigeria Migration Survey 1993, Ibadan, Nigeria: Nigeria Institute for Social and Economic Research.

Nunn, N. (2009): "The Importance of History for Economic Development," Annual Review of Economics, 1(1), 65-92.

Nunn, N. (2010): "Religious Conversion in Colonial Africa," American Economic Review Papers and Proceedings, 100(2), 147-152.

Nunn, N., and L. Wantchekon (2011): "The Slave Trade and the Origins of Mistrust in Africa," 
American Economic Review, 101(7), 3221-3252.

Ogbu, J. U. (1978): Minority Education and Caste: The American System in Cross-Cultural Perspective. San Diego, California.: Academic Press.

Okoye, F. and Y.Z. Yau (1999): The Condition of Almajirai in the North West Zone of Nigeria, Human Rights Monitor.

Okoye, D., and R. Pongou (2015): "Sea Change: The Competing Long-Run Impacts of the Transatlantic Slave Trade and Missionary Activity in Africa," Mimeo.

Osili, U.(2007): "Remittances and Savings from International Migration: Theory and Evidence Using a Matched Sample," Journal of Development Economics, 83(2), 446-465.

Pendakur, K., and R. Pendakur (2005): "Ethnic Identity and the Labour Market," unpublished manuscript, Simon Fraser University.

Phelps, E. (1972): "The Statistical Theory of Racism and Sexism," American Economic Review, 62, 659-661.

Pongou, R., M. Ezzati, and J.A. Salomon (2006): "Household and Community Socioeconomic and Environmental Determinants of Child Nutritional Status in Cameroon," BMC Public Health, 6:98.

Pongou, R., J. A. Salomon, and M. Ezzati (2006): "Health impacts of Macroeconomic Crises and Policies: Determinants of Variation in Childhood Malnutrition Trends in Cameroon," International Journal of Epidemiology, 35, 648-656.

Pritchett, L., and D. Filmer (1999): "What Education Production Functions Really Show: A Positive Theory of Education Expenditure," Economics of Education Review, 18(2), 223-239.

Sen, A.K (1973): On Economic Inequality. Oxford: Clarendon Press.

Sulaiman, K. (2001): "Nigeria's Educational Crisis: The Almajiranci System and Social Realities," Islamic Culture, 75(3), 85-103.

Suleiman, M.D. (1995): "Islamic Education and the Preservation and Transmission of Culture: A Study of the Hausa Migrants in Lokoja, 1903-1933," Tambari: Kano Journal of Education, 2(1), 118-125.

Tabellini, G. (2010): "Culture and Institutions: Economic Development in the Regions of Europe," Journal of the European Economic Association, 8(4), 677-716

Topa, G. (2001): "Social Interactions, Local Spillovers and Unemployment," Review of Economic Studies, 68, 261-95.

Umar, M. S. (2003 ): "Profiles of New Islamic Schools in Northern Nigeria," http://www.international.ucla.edu/cms/files/Profiles_of_Islamic_Schools.pdf (Accessed on May 4, 2010.)

Urwick, J. (1984): "Universal Primary Education in Nigeria: A study of Kano State by Mark Bray," Journal of Modern African Studies, 22 (2), 334-336.

Uwaifo, R. (2008): "Disparities in Labor Market Outcomes across Geopolitical Regions in Nigeria: Fact or Fantasy," IZA working paper. 
Weinreb, L., W. Cheryl, P. Jennifer, S. Richard, H. David, S. Linda, and G. Craig (2002): "Hunger: Its Impact on Children's Health and Mental Health," Pediatrics, 110 (4), e41. Winters, C. A. (1987): "Koranic Education and Militant Islam in Nigeria," International Review of Education, 33(2), 171-185. 
Figure 1-A: Average years of formal education by age and religion

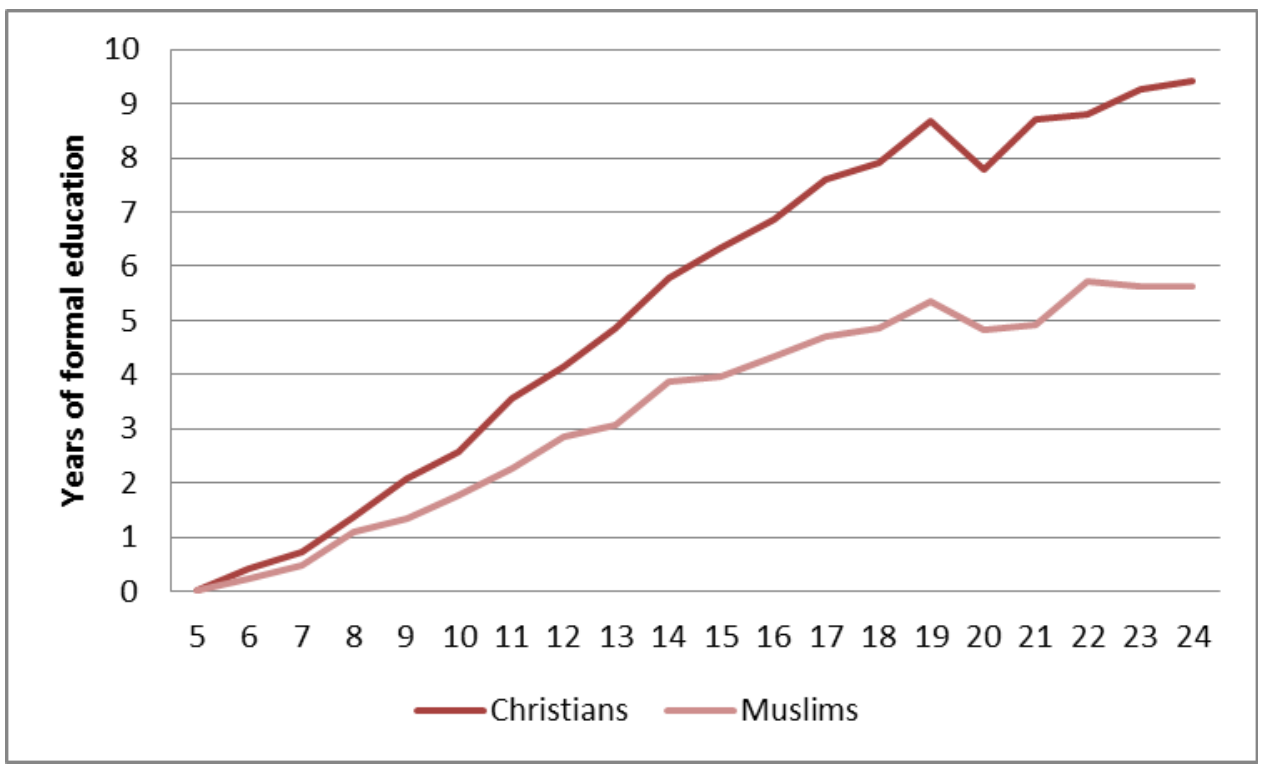

Data Source: Authors’ estimates from the 1999 and 2003 Demographic and Health Surveys

Figure 1-B: Average years of formal education by age and religion adjusted for neighborhood-level education supply

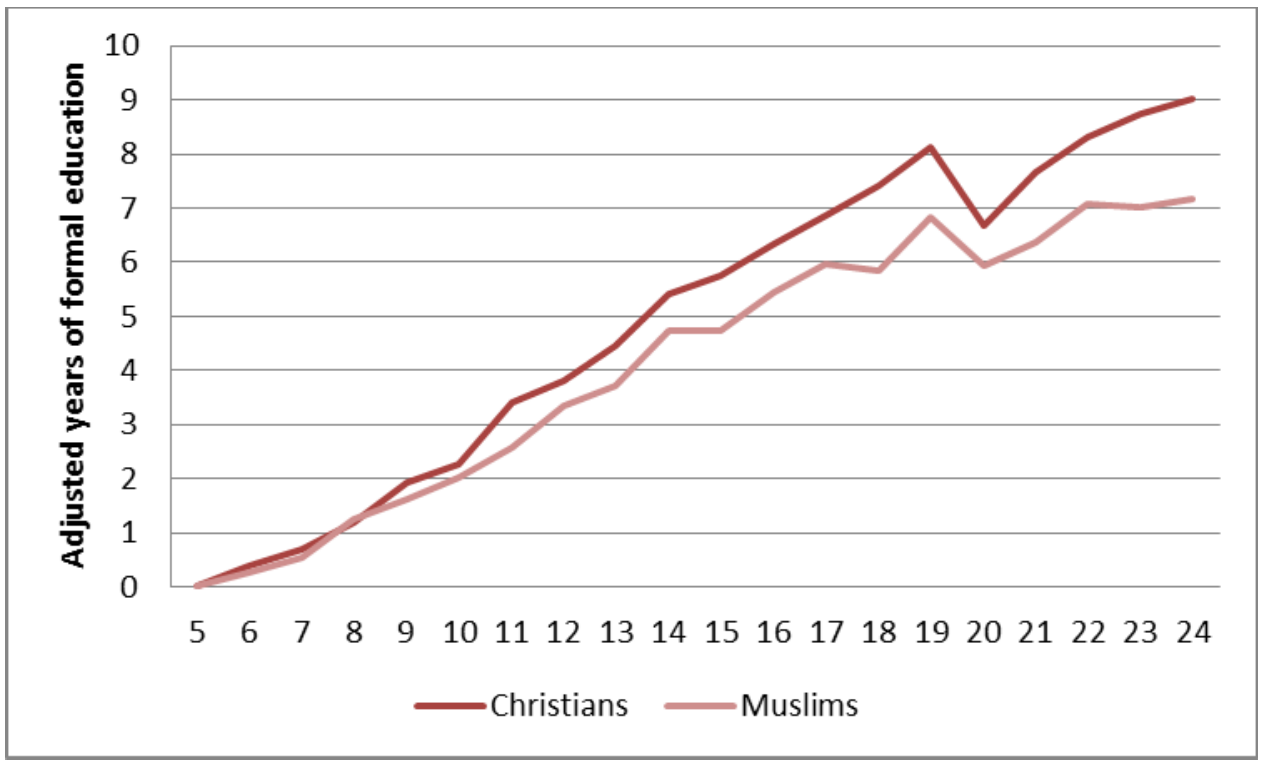

Data Source: Authors' estimates from the 1999 and 2003 Demographic and Health Surveys. Education supply is adjusted by controlling for neighborhood fixed effect in a regression of number of years of formal education acquired by an individual on a binary indicator for being a Muslim. This regression is run for each of the 20 age groups ranging from age 5 to age 24. The number of years of formal education acquired by an average Christian (resp. Muslim) of a given age group is captured by the constant (resp. the sum of the constant and the coefficient on Muslim) of the estimated regression for that age group. 
Figure 2-A: Average years of formal education by age and ethnicity

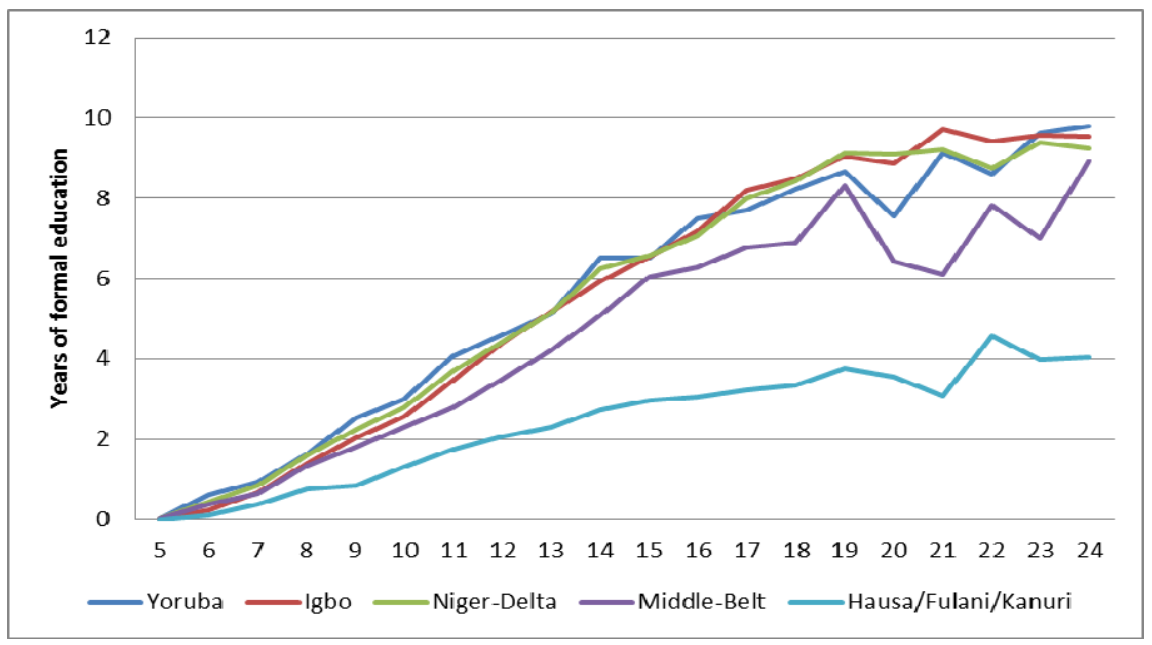

Data Source: Authors' estimates from the 1999 and 2003 Demographic and Health Surveys

Figure 2-B: Average years of formal education by age and ethnicity adjusted for neighborhood-level education supply

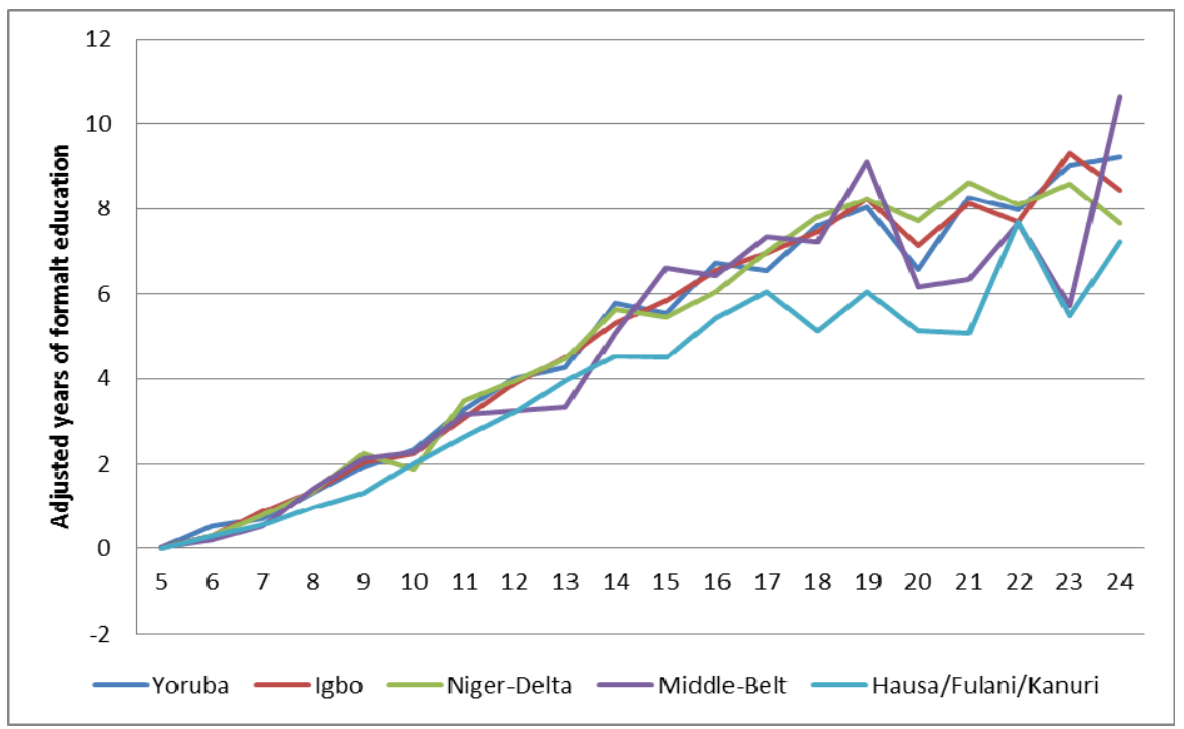

Data Source: Authors' estimates from the 1999 and 2003 Demographic and Health Surveys. Education supply is adjusted by controlling for neighborhood fixed effect in a regression of number of years of formal education acquired by an individual on five binary variables for Igbo, Niger-Delta, Middle-Belt, Hausa/Fulani/Kanuri, and other ethnicity, respectively. This regression is run for each of the 20 age groups ranging from age 5 to age 24. The number of years of formal education acquired by an average Yoruba of a given age group is captured by the constant of the estimated regression for that age group. Similarly, the number of years of formal education acquired by an average individual of a given age group belonging to one of the other ethnic groups is captured by the sum of the constant and the coefficient on the binary indicator for that ethnic group of the estimated regression for that age group. 
Figure 3: Distribution of Christians and Muslims across ethnic groups in Nigeria, 5-24 year olds

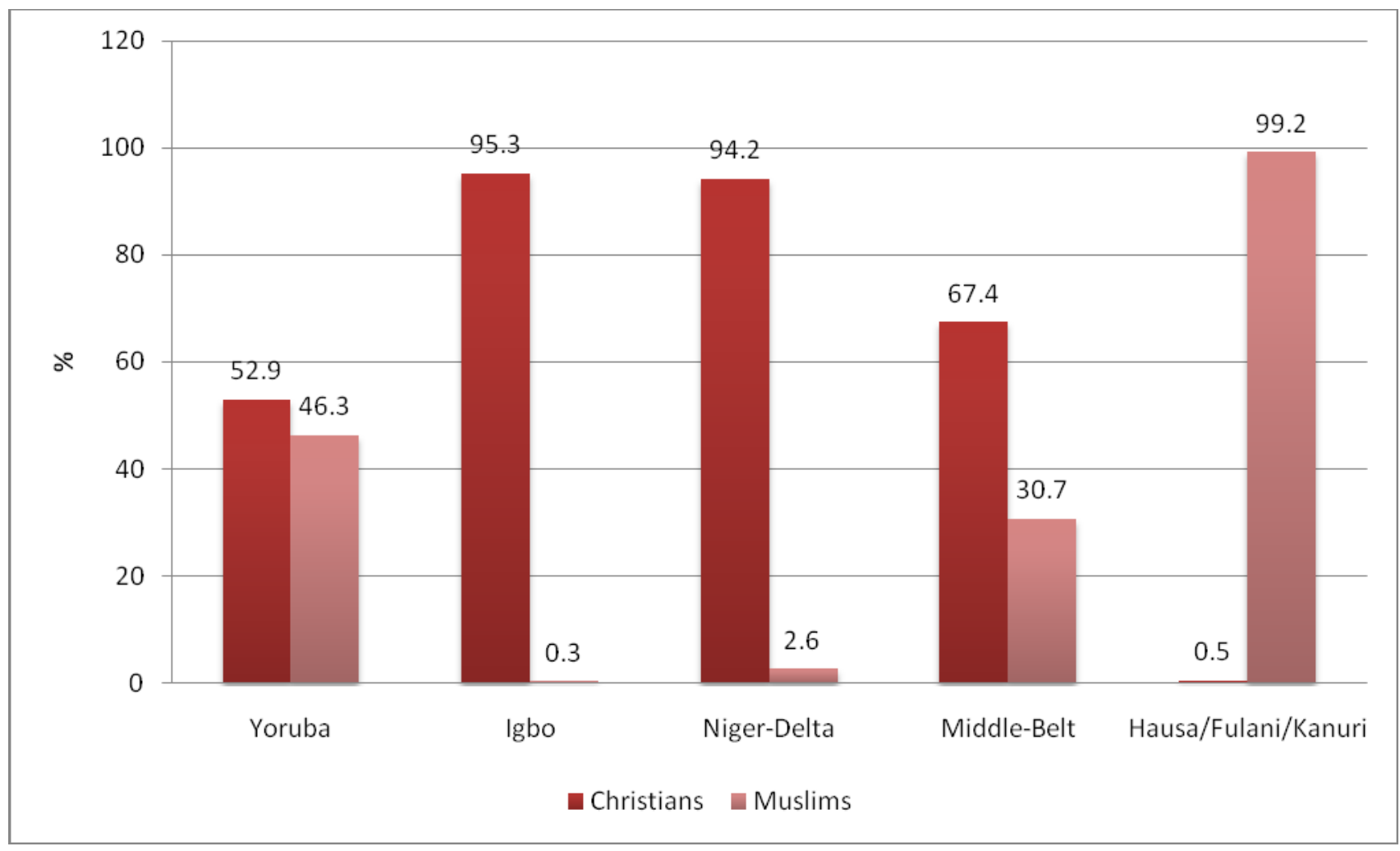

Data Source: Authors’ estimates from the 1999 and 2003 Demographic and Health Surveys 
Figure 4: Proportion (\%) of individuals 5-24 years old with only a Koranic education by ethnicity

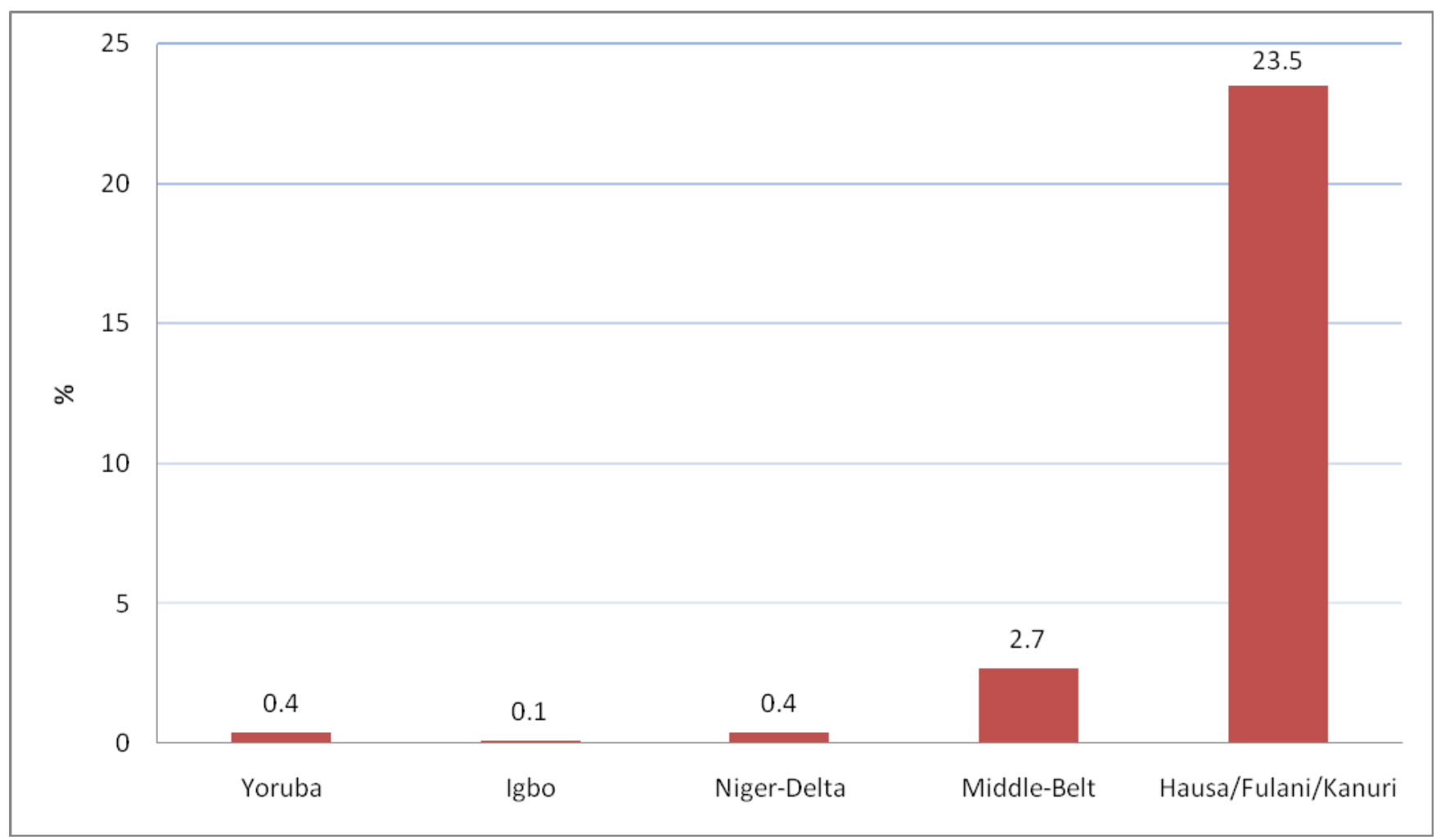

Data Source: Authors’ estimates from the 1993 Nigeria Migration Survey (NISER (1997)) 
Table 1: Summary Statistics

\begin{tabular}{|c|c|c|c|c|c|c|c|c|c|c|c|c|c|c|}
\hline \multirow[b]{2}{*}{ Variables } & \multicolumn{2}{|c|}{ All } & \multicolumn{2}{|c|}{ Yoruba } & \multicolumn{2}{|c|}{ Igbo } & \multicolumn{2}{|c|}{ Niger-Delta } & \multicolumn{2}{|c|}{ Middle-Belt } & \multicolumn{2}{|c|}{ Hausa/Fulani/Kanuri } & \multicolumn{2}{|c|}{ Other ethnicity } \\
\hline & Mean & S.D & Mean & S.D & Mean & S.D & Mean & S.D & Mean & S.D & Mean & S.D & Mean & S.D \\
\hline \multicolumn{15}{|l|}{ Ethnic groups } \\
\hline Yoruba & 0.156 & 0.362 & 1.000 & 0.000 & 0.000 & 0.000 & 0.000 & 0.000 & 0.000 & 0.000 & 0.000 & 0.000 & 0.000 & 0.000 \\
\hline Igbo & 0.157 & 0.364 & 0.000 & 0.000 & 1.000 & 0.000 & 0.000 & 0.000 & 0.000 & 0.000 & 0.000 & 0.000 & 0.000 & 0.000 \\
\hline Niger-Delta & 0.102 & 0.303 & 0.000 & 0.000 & 0.000 & 0.000 & 1.000 & 0.000 & 0.000 & 0.000 & 0.000 & 0.000 & 0.000 & 0.000 \\
\hline Middle-Belt & 0.084 & 0.278 & 0.000 & 0.000 & 0.000 & 0.000 & 0.000 & 0.000 & 1.000 & 0.000 & 0.000 & 0.000 & 0.000 & 0.000 \\
\hline Hausa/Fulani/Kanuri & 0.281 & 0.449 & 0.000 & 0.000 & 0.000 & 0.000 & 0.000 & 0.000 & 0.000 & 0.000 & 1.000 & 0.000 & 0.000 & 0.000 \\
\hline Other ethnicity & 0.220 & 0.414 & 0.000 & 0.000 & 0.000 & 0.000 & 0.000 & 0.000 & 0.000 & 0.000 & 0.000 & 0.000 & 1.000 & 0.000 \\
\hline \multicolumn{15}{|l|}{ Religion } \\
\hline Christian & 0.516 & 0.500 & 0.529 & 0.499 & 0.953 & 0.212 & 0.942 & 0.234 & 0.674 & 0.469 & 0.005 & 0.070 & 0.590 & 0.492 \\
\hline Muslim & 0.465 & 0.499 & 0.463 & 0.499 & 0.003 & 0.054 & 0.026 & 0.159 & 0.307 & 0.461 & 0.992 & 0.092 & 0.390 & 0.488 \\
\hline Other religion & 0.019 & 0.135 & 0.008 & 0.090 & 0.044 & 0.206 & 0.032 & 0.176 & 0.019 & 0.138 & 0.004 & 0.060 & 0.020 & 0.141 \\
\hline Minority & 0.102 & 0.303 & 0.463 & 0.499 & 0.003 & 0.054 & 0.026 & 0.159 & 0.307 & 0.461 & 0.005 & 0.070 & 0.000 & 0.000 \\
\hline \multicolumn{15}{|l|}{ Child characteristics } \\
\hline Male & 0.488 & 0.500 & 0.506 & 0.500 & 0.476 & 0.499 & 0.505 & 0.500 & 0.485 & 0.500 & 0.476 & 0.499 & 0.492 & 0.500 \\
\hline Age & 13.130 & 5.592 & 13.492 & 5.581 & 13.653 & 5.530 & 13.666 & 5.493 & 13.048 & 5.613 & 12.479 & 5.589 & 13.113 & 5.599 \\
\hline $\begin{array}{l}\text { Biological child of household } \\
\text { head (HH) } \\
\text { Household characteristics }\end{array}$ & 0.734 & 0.442 & 0.762 & 0.426 & 0.732 & 0.443 & 0.748 & 0.434 & 0.749 & 0.434 & 0.702 & 0.457 & 0.745 & 0.436 \\
\hline $\mathrm{HH}$ is male & 0.862 & 0.345 & 0.825 & 0.380 & 0.747 & 0.435 & 0.767 & 0.423 & 0.874 & 0.332 & 0.958 & 0.201 & 0.888 & 0.316 \\
\hline Age of $\mathrm{HH}$ & 47.527 & 13.769 & 50.536 & 14.245 & 48.833 & 13.070 & 48.272 & 13.897 & 48.027 & 14.295 & 44.599 & 13.021 & 47.666 & 13.895 \\
\hline HH has no education & 0.373 & 0.484 & 0.284 & 0.451 & 0.218 & 0.413 & 0.156 & 0.363 & 0.308 & 0.462 & 0.617 & 0.486 & 0.360 & 0.480 \\
\hline HH has Primary education & 0.284 & 0.451 & 0.261 & 0.439 & 0.391 & 0.488 & 0.356 & 0.479 & 0.313 & 0.464 & 0.200 & 0.400 & 0.289 & 0.453 \\
\hline HH has Secondary education & 0.212 & 0.409 & 0.277 & 0.448 & 0.264 & 0.441 & 0.331 & 0.471 & 0.215 & 0.411 & 0.110 & 0.313 & 0.202 & 0.402 \\
\hline HH has University education & 0.123 & 0.329 & 0.168 & 0.373 & 0.119 & 0.323 & 0.147 & 0.354 & 0.154 & 0.361 & 0.071 & 0.256 & 0.140 & 0.347 \\
\hline Urban place of residence & 0.359 & 0.480 & 0.573 & 0.495 & 0.410 & 0.492 & 0.248 & 0.432 & 0.267 & 0.443 & 0.324 & 0.468 & 0.302 & 0.459 \\
\hline Wealth & -0.002 & 1.855 & 0.970 & 1.754 & 0.534 & 1.862 & 0.478 & 1.787 & 0.021 & 1.685 & -0.684 & 1.709 & -0.432 & 1.709 \\
\hline Year 1999 & 0.529 & 0.499 & 0.639 & 0.480 & 0.515 & 0.500 & 0.646 & 0.478 & 0.483 & 0.500 & 0.449 & 0.497 & 0.529 & 0.499 \\
\hline Year 2003 & 0.471 & 0.499 & 0.361 & 0.480 & 0.485 & 0.500 & 0.354 & 0.478 & 0.517 & 0.500 & 0.551 & 0.497 & 0.471 & 0.499 \\
\hline
\end{tabular}


Table 2: OLS, state and neighborhood fixed effect estimates of the effects of ethnicity on number of years of formal education among 5-24 year old individuals

\begin{tabular}{|c|c|c|c|c|c|c|}
\hline & (I) & (II) & (III) & (IV) & $(\mathrm{V})$ & (VI) \\
\hline Igbo & $\begin{array}{c}-0.487 * * * \\
(0.171)\end{array}$ & $\begin{array}{c}-0.987 * * * \\
(0.132)\end{array}$ & $\begin{array}{c}-0.667 * * * \\
(0.097)\end{array}$ & $\begin{array}{l}-0.267 * \\
(0.159)\end{array}$ & $\begin{array}{c}-0.122 \\
(0.175)\end{array}$ & $\begin{array}{c}-0.031 \\
(0177)\end{array}$ \\
\hline Niger-Delta & $\begin{array}{c}(0.171) \\
-0.419 * * \\
(0.197)\end{array}$ & $\begin{array}{c}(0.132) \\
-0.973^{* * *} \\
(0.143)\end{array}$ & $\begin{array}{c}\left(0.673^{* * *}\right. \\
(0.123)\end{array}$ & $\begin{array}{c}(0.159) \\
-0.286^{* *} \\
(0.145)\end{array}$ & $\begin{array}{c}(0.175) \\
-0.158 \\
(0.192)\end{array}$ & $\begin{array}{c}(0.177) \\
-0.056 \\
(0.194)\end{array}$ \\
\hline Middle-Belt & $\begin{array}{c}-1.810^{* * *} \\
(0.240)\end{array}$ & $\begin{array}{c}-1.686 * * * \\
(0.192)\end{array}$ & $\begin{array}{c}-1.050 * * * \\
(0.138)\end{array}$ & $\begin{array}{c}-0.769 * * * \\
(0.138)\end{array}$ & $\begin{array}{c}-0.653 * * * \\
(0.189)\end{array}$ & $\begin{array}{c}-0.673 * * * \\
(0.190)\end{array}$ \\
\hline Hausa/Fulani/Kanuri & $\begin{array}{c}-4.049 * * * \\
(0.166)\end{array}$ & $\begin{array}{c}-2.821^{* * *} \\
(0.146)\end{array}$ & $\begin{array}{c}-1.626 * * * \\
(0.105)\end{array}$ & $\begin{array}{c}-1.307 * * * \\
(0.146)\end{array}$ & $\begin{array}{c}-0.963 * * * \\
(0.165)\end{array}$ & $\begin{array}{c}-0.670^{* * *} \\
(0.201)\end{array}$ \\
\hline Other ethnicity & $\begin{array}{c}-1.869 * * * \\
(0.178)\end{array}$ & $\begin{array}{c}-1.700 * * * \\
(0.129)\end{array}$ & $\begin{array}{c}-0.847 * * * \\
(0.092)\end{array}$ & $\begin{array}{c}-0.454^{* * *} \\
(0.109)\end{array}$ & $\begin{array}{c}-0.480 * * * \\
(0.133)\end{array}$ & $\begin{array}{c}-0.288^{*} \\
(0.149)\end{array}$ \\
\hline Muslim & & $\begin{array}{c}-1.091 * * * \\
(0.118)\end{array}$ & $\begin{array}{c}-0.800 * * * \\
(0.090)\end{array}$ & $\begin{array}{c}-0.797 * * * \\
(0.091)\end{array}$ & $\begin{array}{c}-0.544 * * * \\
(0.099)\end{array}$ & $\begin{array}{c}-0.849 * * * \\
(0.162)\end{array}$ \\
\hline Year 2003 & $\begin{array}{c}0.292 * * \\
(0.128)\end{array}$ & $\begin{array}{c}0.018 \\
(0.102)\end{array}$ & $\begin{array}{c}0.021 \\
(0.064)\end{array}$ & $\begin{array}{c}0.011 \\
(0.061)\end{array}$ & - & - \\
\hline Child is male & & $\begin{array}{c}0.433 * * * \\
(0.041)\end{array}$ & $\begin{array}{c}0.386 * * * \\
(0.038)\end{array}$ & $\begin{array}{c}0.391 * * * \\
(0.038)\end{array}$ & $\begin{array}{c}0.386 * * * \\
(0.037)\end{array}$ & $\begin{array}{c}0.385 * * * \\
(0.037)\end{array}$ \\
\hline Child's age & & $\begin{array}{c}0.709 * * * \\
(0.026)\end{array}$ & $\begin{array}{c}0.650 * * * \\
(0.025)\end{array}$ & $\begin{array}{c}0.645^{* * *} \\
(0.025)\end{array}$ & $\begin{array}{c}0.642 * * * \\
(0.025)\end{array}$ & $\begin{array}{c}0.642 * * * \\
(0.025)\end{array}$ \\
\hline$(\text { Child’s age })^{\wedge 2}$ & & $\begin{array}{c}-0.008 * * * \\
(0.001)\end{array}$ & $\begin{array}{c}-0.006 * * * \\
(0.001)\end{array}$ & $\begin{array}{c}-0.006^{* * *} \\
(0.001)\end{array}$ & $\begin{array}{c}-0.006 * * * \\
(0.001)\end{array}$ & $\begin{array}{c}-0.006 * * * \\
(0.001)\end{array}$ \\
\hline Biological child of $\mathrm{HH}$ & & $\begin{array}{c}1.255^{* * *} * \\
(0.070)\end{array}$ & $\begin{array}{c}1.170 * * * \\
(0.059)\end{array}$ & $\begin{array}{c}1.147 * * * \\
(0.059)\end{array}$ & $\begin{array}{c}1.147 * * * \\
(0.059)\end{array}$ & $\begin{array}{c}1.146 * * * \\
(0.059)\end{array}$ \\
\hline $\mathrm{HH}$ is male & & & $\begin{array}{c}-0.972 * * * \\
(0.067)\end{array}$ & $\begin{array}{c}-0.919 * * * \\
(0.065)\end{array}$ & $\begin{array}{c}-0.775^{* * *} \\
(0.065)\end{array}$ & $\begin{array}{c}-0.773 * * * \\
(0.065)\end{array}$ \\
\hline Age of $\mathrm{HH}$ & & & $\begin{array}{c}0.045 * * * \\
(0.009)\end{array}$ & $\begin{array}{c}0.044^{* * *} \\
(0.009)\end{array}$ & $\begin{array}{c}0.035 * * * \\
(0.008)\end{array}$ & $\begin{array}{c}0.035 * * * \\
(0.008)\end{array}$ \\
\hline$(\text { Age of } H H)^{\wedge} 2$ & & & $\begin{array}{l}-0.000 \\
(0.000)\end{array}$ & $\begin{array}{c}-0.000 \\
(0.000)\end{array}$ & $\begin{array}{l}-0.000 \\
(0.000)\end{array}$ & $\begin{array}{l}-0.000 \\
(0.000)\end{array}$ \\
\hline Wealth & & & $\begin{array}{c}0.373 * * * \\
(0.020)\end{array}$ & $\begin{array}{c}0.331 * * * \\
(0.020)\end{array}$ & $\begin{array}{c}0.242 * * * \\
(0.021)\end{array}$ & $\begin{array}{c}0.240 * * * \\
(0.021)\end{array}$ \\
\hline HH has primary education & & & $\begin{array}{c}0.571 * * * \\
(0.055)\end{array}$ & $\begin{array}{c}0.529 * * * \\
(0.054)\end{array}$ & $\begin{array}{c}0.345^{* * *} \\
(0.053)\end{array}$ & $\begin{array}{c}0.342 * * * \\
(0.053)\end{array}$ \\
\hline HH has secondary education & & & $\begin{array}{c}1.186 * * * \\
(0.069)\end{array}$ & $\begin{array}{c}1.082 * * * \\
(0.067)\end{array}$ & $\begin{array}{c}0.835 * * * \\
(0.066)\end{array}$ & $\begin{array}{c}0.830 * * * \\
(0.066)\end{array}$ \\
\hline HH has university education & & & $\begin{array}{c}1.662 * * * \\
(0.092)\end{array}$ & $\begin{array}{c}1.620 * * * \\
(0.090)\end{array}$ & $\begin{array}{c}1.317 * * * \\
(0.091)\end{array}$ & $\begin{array}{c}1.318 * * * \\
(0.091)\end{array}$ \\
\hline Urban place of residence & & & $\begin{array}{c}0.171^{* *} \\
(0.075)\end{array}$ & $\begin{array}{c}0.220 * * * \\
(0.069)\end{array}$ & - & - \\
\hline Minority & & & & & & $\begin{array}{c}0.526 * * * \\
(0.169)\end{array}$ \\
\hline Constant & $\begin{array}{c}5.608 * * * \\
(0.123)\end{array}$ & $\begin{array}{c}-2.844 * * * \\
(0.212)\end{array}$ & $\begin{array}{c}-4.772 * * * \\
(0.295)\end{array}$ & $\begin{array}{c}-5.142 * * * \\
(0.345)\end{array}$ & $\begin{array}{c}-4.706 * * * \\
(0.315)\end{array}$ & $\begin{array}{c}-4.778 * * * \\
(0.313)\end{array}$ \\
\hline State fixed effect (FE) & NO & NO & $\mathrm{NO}$ & YES & - & - \\
\hline Neighborhood FE & NO & NO & NO & NO & YES & YES \\
\hline Observations & 30,746 & 30,746 & 30,746 & 30,746 & 30,746 & 30,746 \\
\hline Number of neighborhoods & 761 & 761 & 761 & 761 & 761 & 761 \\
\hline R-squared & 0.137 & 0.547 & 0.615 & 0.621 & 0.602 & 0.602 \\
\hline \multicolumn{7}{|c|}{$\begin{array}{l}\text { Standard errors in parentheses are clustered at the neighborhood level. In Columns (V) and (VI), Year 2003, Urban and State } \\
\text { dummies are removed after neighborhood fixed effects are included because neighborhoods (or census tracts) sampled in } 1999 \\
\text { are distinct from those sampled in } 2003 \text {, and no neighborhood simultaneously belongs to the urban and the rural area or to two or } \\
\text { more different states. Therefore, controlling for neighborhood fixed effects subsumes or entirely controls for each of the removed } \\
\text { variables. } * * * p<0.01, * * p<0.05, * p<0.1 \text {. }\end{array}$} \\
\hline
\end{tabular}


Table 3: OLS and neighborhood fixed effect estimates of the effects of ethnicity on number of years of formal education by age group.

\begin{tabular}{|c|c|c|c|c|c|c|c|c|}
\hline & \multicolumn{2}{|c|}{ 5-9 years old } & \multicolumn{2}{|c|}{$10-14$ years old } & \multicolumn{2}{|c|}{$15-19$ years old } & \multicolumn{2}{|c|}{ 20-24 years old } \\
\hline & (I) & (II) & (I) & (II) & (I) & (II) & (I) & (II) \\
\hline Igbo & $\begin{array}{c}-0.412 * * * \\
(0.071)\end{array}$ & $\begin{array}{c}-0.137 \\
(0.121)\end{array}$ & $\begin{array}{c}-0.701 * * * \\
(0.134)\end{array}$ & $\begin{array}{c}-0.316 \\
(0.221)\end{array}$ & $\begin{array}{c}-0.457 * * * \\
(0.166)\end{array}$ & $\begin{array}{c}-0.460^{*} \\
(0.253)\end{array}$ & $\begin{array}{c}-0.225 \\
(0.254)\end{array}$ & $\begin{array}{l}-0.415 \\
(0.424)\end{array}$ \\
\hline Niger-Delta & $\begin{array}{c}-0.267 * * * \\
(0.075)\end{array}$ & $\begin{array}{c}-0.071 \\
(0.105)\end{array}$ & $\begin{array}{c}-0.631 * * * \\
(0.175)\end{array}$ & $\begin{array}{c}-0.402 \\
(0.277)\end{array}$ & $\begin{array}{c}-0.501^{* *} \\
(0.236)\end{array}$ & $\begin{array}{l}-0.505 \\
(0.326)\end{array}$ & $\begin{array}{c}-0.242 \\
(0.285)\end{array}$ & $\begin{array}{c}-0.187 \\
(0.450)\end{array}$ \\
\hline Middle-Belt & $\begin{array}{c}-0.507 * * * \\
(0.083)\end{array}$ & $\begin{array}{c}-0.166 \\
(0.127)\end{array}$ & $\begin{array}{c}-1.586^{* * *} \\
(0.212)\end{array}$ & $\begin{array}{c}-0.795^{* *} \\
(0.355)\end{array}$ & $\begin{array}{c}-1.486^{* * *} \\
(0.296)\end{array}$ & $\begin{array}{c}-0.418 \\
(0.378)\end{array}$ & $\begin{array}{c}-2.703^{* * *} \\
(0.373)\end{array}$ & $\begin{array}{c}-1.387 * * * \\
(0.476)\end{array}$ \\
\hline Hausa/Fulani/Kanuri & $\begin{array}{c}-0.924^{* * *} \\
(0.061)\end{array}$ & $\begin{array}{c}-0.434^{* * *} \\
(0.106)\end{array}$ & $\begin{array}{c}-2.983^{* * *} \\
(0.151)\end{array}$ & $\begin{array}{c}-1.006^{* * *} \\
(0.247)\end{array}$ & $\begin{array}{c}-4.540^{* * *} \\
(0.249)\end{array}$ & $\begin{array}{c}-1.240^{* * *} \\
(0.351)\end{array}$ & $\begin{array}{c}-5.367 * * * \\
(0.287)\end{array}$ & $\begin{array}{c}-1.740^{* * *} \\
(0.400)\end{array}$ \\
\hline Other ethnicity & $\begin{array}{c}-0.556^{* * *} \\
(0.065)\end{array}$ & $\begin{array}{c}-0.289 * * * \\
(0.095)\end{array}$ & $\begin{array}{c}-1.736^{* * *} \\
(0.156)\end{array}$ & $\begin{array}{c}-0.749 * * * \\
(0.212)\end{array}$ & $\begin{array}{c}-2.166^{* * *} \\
(0.212)\end{array}$ & $\begin{array}{c}-0.836 * * * \\
(0.235)\end{array}$ & $\begin{array}{c}-1.969 * * * \\
(0.260)\end{array}$ & $\begin{array}{c}-0.473 \\
(0.324)\end{array}$ \\
\hline Muslim & & $\begin{array}{c}-0.053 \\
(0.057)\end{array}$ & & $\begin{array}{c}-0.479 * * * \\
(0.128)\end{array}$ & & $\begin{array}{c}-0.820^{* * *} \\
(0.157)\end{array}$ & & $\begin{array}{c}-0.736 * * * \\
(0.265)\end{array}$ \\
\hline Year 2003 & $\begin{array}{c}-0.233^{* * *} \\
(0.037)\end{array}$ & - & $\begin{array}{c}-0.255^{* *} \\
(0.101)\end{array}$ & - & $\begin{array}{c}0.327 * \\
(0.167)\end{array}$ & - & $\begin{array}{c}0.764^{* * *} \\
(0.215)\end{array}$ & - \\
\hline Child is male & & $\begin{array}{c}0.030 \\
(0.021)\end{array}$ & & $\begin{array}{c}0.245^{* * *} \\
(0.050)\end{array}$ & & $\begin{array}{c}0.583 * * * \\
(0.078)\end{array}$ & & $\begin{array}{c}0.857 * * * \\
(0.113)\end{array}$ \\
\hline Child age & & $\begin{array}{c}-0.304^{* * *} \\
(0.083)\end{array}$ & & $\begin{array}{c}-0.017 \\
(0.317)\end{array}$ & & $\begin{array}{c}0.029 \\
(0.689)\end{array}$ & & $\begin{array}{c}1.476 \\
(1.127)\end{array}$ \\
\hline$(\text { Child age })^{\wedge} 2$ & & $\begin{array}{c}0.052 * * * \\
(0.006)\end{array}$ & & $\begin{array}{c}0.027 * * \\
(0.013)\end{array}$ & & $\begin{array}{c}0.013 \\
(0.020)\end{array}$ & & $\begin{array}{l}-0.029 \\
(0.026)\end{array}$ \\
\hline Biological child of $\mathrm{HH}$ & & $\begin{array}{c}0.027 \\
(0.042)\end{array}$ & & $\begin{array}{c}0.465^{* * *} \\
(0.069)\end{array}$ & & $\begin{array}{c}0.945^{* * *} \\
(0.104)\end{array}$ & & $\begin{array}{c}1.878 * * * \\
(0.152)\end{array}$ \\
\hline $\mathrm{HH}$ is male & & $\begin{array}{c}-0.151^{* * *} \\
(0.049)\end{array}$ & & $\begin{array}{c}-0.391 * * * \\
(0.085)\end{array}$ & & $\begin{array}{c}-0.738 * * * \\
(0.123)\end{array}$ & & $\begin{array}{c}-1.084 * * * \\
(0.162)\end{array}$ \\
\hline Age of $\mathrm{HH}$ & & $\begin{array}{l}0.011^{*} \\
(0.006)\end{array}$ & & $\begin{array}{c}0.017 \\
(0.013)\end{array}$ & & $\begin{array}{c}0.012 \\
(0.015)\end{array}$ & & $\begin{array}{c}-0.063 * * * \\
(0.019)\end{array}$ \\
\hline$(\text { Age of } \mathrm{HH})^{\wedge} 2$ & & $\begin{array}{c}-0.000 \\
(0.000)\end{array}$ & & $\begin{array}{c}-0.000 \\
(0.000)\end{array}$ & & $\begin{array}{c}0.000 \\
(0.000)\end{array}$ & & $\begin{array}{c}0.001^{* * *} \\
(0.000)\end{array}$ \\
\hline Wealth & & $\begin{array}{c}0.076^{* * *} \\
(0.013)\end{array}$ & & $\begin{array}{c}0.208 * * * \\
(0.028)\end{array}$ & & $\begin{array}{c}0.392 * * * \\
(0.039)\end{array}$ & & $\begin{array}{c}0.418^{* * * *} \\
(0.055)\end{array}$ \\
\hline HH has primary education & & $\begin{array}{c}0.088 * * * \\
(0.033)\end{array}$ & & $\begin{array}{c}0.280 * * * \\
(0.082)\end{array}$ & & $\begin{array}{c}0.502 * * * \\
(0.115)\end{array}$ & & $\begin{array}{c}0.974 * * * \\
(0.152)\end{array}$ \\
\hline $\begin{array}{l}\text { HH has secondary } \\
\text { education }\end{array}$ & & $\begin{array}{c}0.125 * * * \\
(0.040)\end{array}$ & & $\begin{array}{c}0.512 * * * \\
(0.098)\end{array}$ & & $\begin{array}{c}1.115^{* * *} \\
(0.138)\end{array}$ & & $\begin{array}{c}2.332 * * * \\
(0.188)\end{array}$ \\
\hline $\begin{array}{l}\text { HH has university } \\
\text { education }\end{array}$ & & $\begin{array}{c}0.311^{* * *} \\
(0.062)\end{array}$ & & $\begin{array}{c}1.226 * * * \\
(0.119)\end{array}$ & & $\begin{array}{c}1.628 * * * \\
(0.172)\end{array}$ & & $\begin{array}{c}3.154 * * * \\
(0.246)\end{array}$ \\
\hline Urban place of residence & & - & & - & & - & & - \\
\hline Constant & $\begin{array}{c}1.435^{* * *} \\
(0.058)\end{array}$ & $\begin{array}{c}0.262 \\
(0.330)\end{array}$ & $\begin{array}{c}5.138 * * * \\
(0.108)\end{array}$ & $\begin{array}{c}-0.370 \\
(1.891)\end{array}$ & $\begin{array}{c}7.922 * * * \\
(0.144)\end{array}$ & $\begin{array}{c}1.497 \\
(5.819)\end{array}$ & $\begin{array}{c}8.774^{* * * *} \\
(0.202)\end{array}$ & $\begin{array}{c}-10.433 \\
(12.240)\end{array}$ \\
\hline Neighborhood FE & NO & YES & NO & YES & NO & YES & NO & YES \\
\hline Observations & 10,384 & 10,384 & 7,947 & 7,947 & 6,909 & 6,909 & 5,506 & 5,506 \\
\hline Number of neighborhoods & 756 & 756 & 759 & 759 & 751 & 751 & 747 & 747 \\
\hline R-squared & 0.086 & 0.332 & 0.201 & 0.416 & 0.201 & 0.484 & 0.277 & 0.533 \\
\hline $\begin{array}{l}\text { Standard errors in parenthe } \\
\text { removed after neighborhoc } \\
\text { from those sampled in } 200 \\
\text { different states. Therefore, } \\
\text { variables. } *^{* *} \mathrm{p}<0.01,{ }^{* *} \mathrm{p}\end{array}$ & $\begin{array}{l}\text { es are cluste } \\
d \text { fixed effe } \\
3 \text {, and no n } \\
\text { controlling } \\
<0.05,{ }^{*} \mathrm{p}<0\end{array}$ & $\begin{array}{l}\text { ed at the nei } \\
\text { ts are includ } \\
\text { ighborhood } \\
\text { or neighborl } \\
1 .\end{array}$ & $\begin{array}{l}\text { hborhood } \\
\text { d because } \\
\text { multaneou } \\
\text { od fixed }\end{array}$ & $\begin{array}{l}\text { el. In Col } \\
\text { eighborho } \\
\text { y belongs } \\
\text { fects subs }\end{array}$ & $\begin{array}{l}\text { nns (II), Ye } \\
\text { s (or censu } \\
\text { the urban } \\
\text { les or enti }\end{array}$ & $\begin{array}{l}\text { 2003, Urb } \\
\text { tracts) san } \\
\text { nd the rur } \\
\text { y controls }\end{array}$ & $\begin{array}{l}\text { and State } \\
\text { led in } 1999 \\
\text { area or to t } \\
\text { r each of }\end{array}$ & $\begin{array}{l}\text { ummies are } \\
\text { are distinct } \\
\text { vo or more } \\
\text { e removed }\end{array}$ \\
\hline
\end{tabular}


Table 4: OLS and neighborhood fixed effect estimates of the effects of ethnicity on primary, secondary and university education

\begin{tabular}{|c|c|c|c|c|c|c|}
\hline & \multicolumn{2}{|c|}{ Primary education } & \multicolumn{2}{|c|}{ Secondary education } & \multicolumn{2}{|c|}{ University education } \\
\hline & (I) & (II) & (I) & (II) & (I) & (II) \\
\hline Igbo & $\begin{array}{l}-0.013 \\
(0.016)\end{array}$ & $\begin{array}{c}-0.047^{*} \\
(0.025)\end{array}$ & $\begin{array}{c}-0.008 \\
(0.018)\end{array}$ & $\begin{array}{c}0.028 \\
(0.022)\end{array}$ & $\begin{array}{c}-0.011^{* *} \\
(0.005)\end{array}$ & $\begin{array}{l}-0.011 \\
(0.011)\end{array}$ \\
\hline Niger-Delta & $\begin{array}{c}0.014 \\
(0.022)\end{array}$ & $\begin{array}{l}-0.041 \\
(0.029)\end{array}$ & $\begin{array}{l}-0.002 \\
(0.020)\end{array}$ & $\begin{array}{l}-0.008 \\
(0.026)\end{array}$ & $\begin{array}{l}-0.005 \\
(0.006)\end{array}$ & $\begin{array}{c}0.005 \\
(0.012)\end{array}$ \\
\hline Middle-Belt & $\begin{array}{l}-0.002 \\
(0.021)\end{array}$ & $\begin{array}{l}-0.000 \\
(0.027)\end{array}$ & $\begin{array}{c}-0.116^{* * * *} \\
(0.023)\end{array}$ & $\begin{array}{l}-0.015 \\
(0.022)\end{array}$ & $\begin{array}{c}-0.019 * * * \\
(0.005)\end{array}$ & $\begin{array}{c}-0.023^{* *} \\
(0.010)\end{array}$ \\
\hline Hausa/Fulani/Kanuri & $\begin{array}{c}-0.226^{* * *} \\
(0.017)\end{array}$ & $\begin{array}{c}-0.071 * * * \\
(0.027)\end{array}$ & $\begin{array}{c}-0.295 * * * \\
(0.016)\end{array}$ & $\begin{array}{c}-0.043 * * \\
(0.020)\end{array}$ & $\begin{array}{c}-0.023^{* * * *} \\
(0.004)\end{array}$ & $\begin{array}{c}-0.009 \\
(0.009)\end{array}$ \\
\hline Other ethnicity & $\begin{array}{c}-0.048^{* * *} \\
(0.018)\end{array}$ & $\begin{array}{l}-0.030 \\
(0.023)\end{array}$ & $\begin{array}{c}-0.124 * * * \\
(0.017)\end{array}$ & $\begin{array}{l}-0.005 \\
(0.018)\end{array}$ & $\begin{array}{c}-0.014^{* * *} \\
(0.005)\end{array}$ & $\begin{array}{l}-0.010 \\
(0.008)\end{array}$ \\
\hline Muslim & & $\begin{array}{c}0.015 \\
(0.013)\end{array}$ & & $\begin{array}{c}-0.053^{* * *} \\
(0.011)\end{array}$ & & $\begin{array}{c}-0.006 \\
(0.005)\end{array}$ \\
\hline Year 2003 & $\begin{array}{l}0.020^{*} \\
(0.012)\end{array}$ & - & $\begin{array}{c}0.027 * * \\
(0.011)\end{array}$ & - & $\begin{array}{c}0.009 * * * \\
(0.003)\end{array}$ & - \\
\hline Child is male & & $\begin{array}{c}0.023^{* * *} \\
(0.006)\end{array}$ & & $\begin{array}{c}0.032 * * * \\
(0.004)\end{array}$ & & $\begin{array}{c}0.002 \\
(0.002)\end{array}$ \\
\hline Child age & & $\begin{array}{c}0.068 * * * \\
(0.004)\end{array}$ & & $\begin{array}{c}0.069 * * * \\
(0.004)\end{array}$ & & $\begin{array}{c}-0.018 * * * \\
(0.001)\end{array}$ \\
\hline$(\text { Child age })^{\wedge 2}$ & & $\begin{array}{c}-0.003^{* * *} \\
(0.000)\end{array}$ & & $\begin{array}{c}-0.001^{* * *} \\
(0.000)\end{array}$ & & $\begin{array}{c}0.001 * * * \\
(0.000)\end{array}$ \\
\hline Biological child of $\mathrm{HH}$ & & $\begin{array}{c}-0.056 * * * \\
(0.008)\end{array}$ & & $\begin{array}{c}0.105^{* * *} \\
(0.007)\end{array}$ & & $\begin{array}{c}0.021 * * * \\
(0.003)\end{array}$ \\
\hline $\mathrm{HH}$ is male & & $\begin{array}{l}-0.002 \\
(0.009)\end{array}$ & & $\begin{array}{c}-0.052^{* * * *} \\
(0.008)\end{array}$ & & $\begin{array}{c}-0.017 * * * \\
(0.003)\end{array}$ \\
\hline Age of $\mathrm{HH}$ & & $\begin{array}{c}-0.001 \\
(0.001)\end{array}$ & & $\begin{array}{c}0.004^{* * *} \\
(0.001)\end{array}$ & & $\begin{array}{c}0.000 \\
(0.000)\end{array}$ \\
\hline$(\text { Age of } \mathrm{HH})^{\wedge} 2$ & & $\begin{array}{c}0.000 \\
(0.000)\end{array}$ & & $\begin{array}{c}-0.000^{*} \\
(0.000)\end{array}$ & & $\begin{array}{c}0.000 \\
(0.000)\end{array}$ \\
\hline Wealth & & $\begin{array}{l}-0.004 \\
(0.003)\end{array}$ & & $\begin{array}{c}0.023 * * * \\
(0.002)\end{array}$ & & $\begin{array}{c}0.004^{* * *} \\
(0.001)\end{array}$ \\
\hline HH has primary education & & $\begin{array}{c}0.085^{* * * *} \\
(0.009)\end{array}$ & & $\begin{array}{c}0.001 \\
(0.006)\end{array}$ & & $\begin{array}{c}0.002 \\
(0.002)\end{array}$ \\
\hline HH has secondary education & & $\begin{array}{c}0.072 * * * \\
(0.011)\end{array}$ & & $\begin{array}{c}0.062^{* * * *} \\
(0.008)\end{array}$ & & $\begin{array}{c}0.001 \\
(0.003)\end{array}$ \\
\hline HH has university education & & $\begin{array}{c}0.046 * * * \\
(0.014)\end{array}$ & & $\begin{array}{c}0.062 * * * \\
(0.010)\end{array}$ & & $\begin{array}{c}0.039 * * * \\
(0.005)\end{array}$ \\
\hline Urban place of residence & & - & & - & & - \\
\hline Constant & $\begin{array}{c}0.472^{* * *} \\
(0.013)\end{array}$ & $\begin{array}{c}0.264^{* * *} \\
(0.045)\end{array}$ & $\begin{array}{c}0.371^{* * *} \\
(0.014)\end{array}$ & $\begin{array}{c}-0.589 * * * \\
(0.041)\end{array}$ & $\begin{array}{c}0.027 * * * \\
(0.004)\end{array}$ & $\begin{array}{c}0.079 * * * \\
(0.016)\end{array}$ \\
\hline Neighborhood fixed effect & NO & YES & NO & YES & NO & YES \\
\hline Observations & 30,746 & 30,746 & 30,746 & 30,746 & 30,746 & 30,746 \\
\hline Number of neighborhoods & 761 & 761 & 761 & 761 & 761 & 761 \\
\hline R-squared & 0.038 & 0.129 & 0.072 & 0.353 & 0.004 & 0.103 \\
\hline $\begin{array}{l}\text { Standard errors in parenthese } \\
\text { removed after neighborhood } \\
\text { from those sampled in } 2003 \text {, } \\
\text { different states. Therefore, c } \\
\text { variables. } * * * p<0.01, * * p<0\end{array}$ & $\begin{array}{l}\text { ustered at th } \\
\text { effects are i } \\
\text { o neighborl } \\
\text { ing for neig } \\
\mathrm{p}<0.1 \text {. }\end{array}$ & $\begin{array}{l}\text { ighborhood } \\
\text { ded because } \\
\text { simultaneo } \\
\text { rhood fixed }\end{array}$ & $\begin{array}{l}\text { el. In Colun } \\
\text { ighborhood } \\
\text { belongs to } \\
\text { ects subsum }\end{array}$ & $\begin{array}{l}\text { II), Year } 20 \\
\text { census tra } \\
\text { urban and } \\
\text { r entirely }\end{array}$ & $\begin{array}{l}\text { Jrban and S } \\
\text { sampled in } \\
\text { ural area o } \\
\text { ols for each }\end{array}$ & $\begin{array}{l}\text { dummies ar } \\
\text { are distinc } \\
\text { two or mor } \\
\text { the remove }\end{array}$ \\
\hline
\end{tabular}


Table 5: OLS and neighborhood fixed effect estimates of the effects of ethnicity on number of years of formal education by parental education (or child ability)

\begin{tabular}{|c|c|c|c|c|c|}
\hline \multirow[t]{2}{*}{ Panel A } & \multicolumn{5}{|c|}{ Analysis restricted to children whose household head has: } \\
\hline & $\begin{array}{l}\text { Some or no } \\
\text { education }\end{array}$ & No education & $\begin{array}{c}\text { Primary } \\
\text { education }\end{array}$ & $\begin{array}{l}\text { Secondary } \\
\text { education }\end{array}$ & $\begin{array}{l}\text { University } \\
\text { education }\end{array}$ \\
\hline Igbo & $\begin{array}{c}-0.461^{* * *} \\
(0.103)\end{array}$ & $\begin{array}{l}-1.577^{*} \\
(0.930)\end{array}$ & $\begin{array}{l}-0.545^{*} \\
(0.315)\end{array}$ & $\begin{array}{c}0.252 \\
(0.192)\end{array}$ & $\begin{array}{l}-0.155 \\
(0.270)\end{array}$ \\
\hline Niger-Delta & $\begin{array}{c}-0.429 * * * \\
(0.119)\end{array}$ & $\begin{array}{l}-0.360 \\
(0.721)\end{array}$ & $\begin{array}{l}-0.161 \\
(0.337)\end{array}$ & $\begin{array}{c}0.041 \\
(0.251)\end{array}$ & $\begin{array}{c}0.018 \\
(0.323)\end{array}$ \\
\hline Middle-Belt & $\begin{array}{c}-1.013 * * * \\
(0.133)\end{array}$ & $\begin{array}{c}-1.454^{* * *} \\
(0.532)\end{array}$ & $\begin{array}{l}-0.417 \\
(0.323)\end{array}$ & $\begin{array}{l}-0.507^{*} \\
(0.286)\end{array}$ & $\begin{array}{c}-0.923 * * \\
(0.366)\end{array}$ \\
\hline Hausa/Fulani/Kanuri & $\begin{array}{c}-1.605^{* * *} \\
(0.104)\end{array}$ & $\begin{array}{c}-1.659 * * * \\
(0.458)\end{array}$ & $\begin{array}{c}-0.521 \\
(0.317)\end{array}$ & $\begin{array}{c}-1.244^{* * *} \\
(0.294)\end{array}$ & $\begin{array}{l}-0.365 \\
(0.364)\end{array}$ \\
\hline Other ethnicity & $\begin{array}{c}-0.854 * * * \\
(0.090)\end{array}$ & $\begin{array}{c}-1.358^{* * *} \\
(0.439)\end{array}$ & $\begin{array}{c}-0.490 * * \\
(0.231)\end{array}$ & $\begin{array}{l}-0.053 \\
(0.228)\end{array}$ & $\begin{array}{c}-0.555^{* *} \\
(0.250)\end{array}$ \\
\hline Constant & $\begin{array}{c}-4.566^{* * *} \\
(0.290)\end{array}$ & $\begin{array}{c}-2.660^{* * *} \\
(0.665)\end{array}$ & $\begin{array}{c}-6.340^{* * *} \\
(0.488)\end{array}$ & $\begin{array}{c}-4.242^{* * *} \\
(0.477)\end{array}$ & $\begin{array}{l}-1.080 \\
(0.952)\end{array}$ \\
\hline Controls & YES & YES & YES & YES & YES \\
\hline Neighborhood fixed effect & YES & YES & YES & YES & YES \\
\hline Observations & 30,746 & 11,474 & 8,741 & 6,525 & 3,793 \\
\hline Number of neighborhoods & 761 & 668 & 690 & 623 & 434 \\
\hline R-squared & 0.613 & 0.512 & 0.631 & 0.674 & 0.730 \\
\hline \multirow[t]{2}{*}{ Panel B } & \multicolumn{5}{|c|}{ Analysis restricted to Muslim children whose household head has: } \\
\hline & $\begin{array}{l}\text { Some or no } \\
\text { education }\end{array}$ & No education & $\begin{array}{c}\text { Primary } \\
\text { education }\end{array}$ & $\begin{array}{l}\text { Secondary } \\
\text { education }\end{array}$ & $\begin{array}{l}\text { University } \\
\text { education }\end{array}$ \\
\hline Igbo & $\begin{array}{c}0.990 \\
(0.939)\end{array}$ & $\begin{array}{c}5.984 * * * \\
(0.185)\end{array}$ & $\begin{array}{c}0.138 \\
(0.985)\end{array}$ & $\begin{array}{l}-0.354^{*} \\
(0.196)\end{array}$ & $\begin{array}{c}3.162 * * * \\
(0.943)\end{array}$ \\
\hline Niger-Delta & $\begin{array}{l}1.489 * \\
(0.824)\end{array}$ & $\begin{array}{c}0.491 \\
(0.500)\end{array}$ & $\begin{array}{l}-0.219 \\
(0.628)\end{array}$ & $\begin{array}{c}2.362 \\
(1.897)\end{array}$ & $\begin{array}{c}0.057 \\
(0.998)\end{array}$ \\
\hline Middle-Belt & $\begin{array}{c}-0.482 \\
(0.335)\end{array}$ & $\begin{array}{c}-1.389 * * \\
(0.630)\end{array}$ & $\begin{array}{c}0.095 \\
(0.869)\end{array}$ & $\begin{array}{l}-0.766 \\
(0.718)\end{array}$ & $\begin{array}{c}0.094 \\
(0.965)\end{array}$ \\
\hline Hausa/Fulani/Kanuri & $\begin{array}{c}-0.724 * * * \\
(0.252)\end{array}$ & $\begin{array}{c}-1.512 * * * \\
(0.514)\end{array}$ & $\begin{array}{l}-0.424 \\
(0.406)\end{array}$ & $\begin{array}{l}-0.578 \\
(0.601)\end{array}$ & $\begin{array}{c}0.579 \\
(0.763)\end{array}$ \\
\hline Other ethnicities & $\begin{array}{l}-0.420^{*} \\
(0.251)\end{array}$ & $\begin{array}{c}-1.235^{* * *} \\
(0.491)\end{array}$ & $\begin{array}{l}-0.503 \\
(0.353)\end{array}$ & $\begin{array}{c}0.709 \\
(0.638)\end{array}$ & $\begin{array}{l}-0.012 \\
(0.920)\end{array}$ \\
\hline Constant & $\begin{array}{c}-3.454 * * * \\
(0.478)\end{array}$ & $\begin{array}{c}-2.050 * * * \\
(0.703)\end{array}$ & $\begin{array}{c}-3.618 * * * \\
(0.968)\end{array}$ & $\begin{array}{c}-3.458 * * * \\
(1.154)\end{array}$ & $\begin{array}{l}-1.607 \\
(2.802)\end{array}$ \\
\hline Controls & YES & YES & YES & YES & YES \\
\hline Neighborhood fixed effect & YES & YES & YES & YES & YES \\
\hline Observations & 14,304 & 7,867 & 3,158 & 2,017 & 1,194 \\
\hline Number of neighborhoods & 479 & 403 & 358 & 314 & 190 \\
\hline R-squared & 0.469 & 0.411 & 0.497 & 0.524 & 0.578 \\
\hline
\end{tabular}


Table 6: OLS and neighborhood fixed effect estimates of the effects of ethnicity on number of years of formal education by parental wealth (or child ability)

\begin{tabular}{|c|c|c|c|c|c|}
\hline \multirow[t]{2}{*}{ Panel A } & \multicolumn{5}{|c|}{$\begin{array}{l}\text { Analysis restricted to children whose household fall into the following wealth } \\
\text { quintile: }\end{array}$} \\
\hline & $1^{\text {st }}$ quintile & $2^{\text {nd }}$ quintile & $3^{\text {rd }}$ quintile & $4^{\text {th }}$ quintile & $5^{\text {th }}$ quintile \\
\hline \multirow[t]{2}{*}{ Igbo } & $-1.840 * *$ & $-1.179 * *$ & 0.463 & 0.015 & -0.137 \\
\hline & $(0.744)$ & $(0.545)$ & $(0.529)$ & $(0.268)$ & $(0.186)$ \\
\hline \multirow[t]{2}{*}{ Niger-Delta } & -0.767 & -0.810 & -0.180 & -0.255 & 0.105 \\
\hline & $(0.819)$ & $(0.505)$ & $(0.576)$ & $(0.309)$ & $(0.224)$ \\
\hline \multirow[t]{2}{*}{ Middle-Belt } & -1.098 & $-1.126^{*}$ & -0.050 & $-0.781^{* *}$ & -0.293 \\
\hline & $(0.694)$ & $(0.680)$ & $(0.524)$ & $(0.332)$ & $(0.309)$ \\
\hline \multirow[t]{2}{*}{ Hausa/Fulani/Kanuri } & $-1.621^{* * *}$ & $-1.321^{* *}$ & $-0.923^{*}$ & $-0.989 * * *$ & $-0.696 * * *$ \\
\hline & $(0.609)$ & $(0.551)$ & $(0.560)$ & $(0.301)$ & $(0.240)$ \\
\hline \multirow[t]{2}{*}{ Other ethnicity } & $-1.221 * *$ & $-0.891^{*}$ & 0.147 & $-0.430 *$ & $-0.525^{* * *}$ \\
\hline & $(0.570)$ & $(0.498)$ & $(0.425)$ & $(0.241)$ & $(0.183)$ \\
\hline \multirow[t]{2}{*}{ Constant } & -1.231 & $-3.043 * * *$ & $-4.959 * * *$ & $-6.282 * * *$ & $-6.314 * * *$ \\
\hline & $(0.765)$ & $(0.947)$ & $(0.750)$ & $(0.598)$ & $(0.666)$ \\
\hline Controls & YES & YES & YES & YES & YES \\
\hline Neighborhood fixed effect & YES & YES & YES & YES & YES \\
\hline Observations & 7,717 & 4,278 & 5,910 & 6,610 & 6,231 \\
\hline Number of neighborhoods & 454 & 440 & 557 & 522 & 401 \\
\hline R-squared & 0.403 & 0.512 & 0.551 & 0.653 & 0.729 \\
\hline \multirow[t]{2}{*}{ Panel B } & \multicolumn{5}{|c|}{$\begin{array}{c}\text { Analysis restricted to children whose household fall into the following wealth } \\
\text { quintile: }\end{array}$} \\
\hline & $1^{\text {st }}$ quintile & $2^{\text {nd }}$ quintile & $3^{\text {rd }}$ quintile & $4^{\text {th }}$ quintile & $5^{\text {th }}$ quintile \\
\hline Igbo & - & - & - & $\begin{array}{c}1.442 * * * \\
(0.256)\end{array}$ & $\begin{array}{c}1.185 \\
(0.735)\end{array}$ \\
\hline \multirow[t]{2}{*}{ Niger-Delta } & $-1.621^{* * *}$ & 0.325 & -0.932 & 0.509 & $2.582 * * *$ \\
\hline & $(0.524)$ & $(0.788)$ & (1.069) & (1.189) & $(0.865)$ \\
\hline \multirow[t]{2}{*}{ Middle-Belt } & $-2.785 * * *$ & 0.710 & 0.318 & $-1.108^{*}$ & 0.112 \\
\hline & $(0.654)$ & $(0.890)$ & (1.088) & $(0.564)$ & $(0.854)$ \\
\hline \multirow{2}{*}{ Hausa/Fulani/Kanuri } & $-3.114 * * *$ & -0.730 & -0.761 & $-1.002 * *$ & $-0.787 * *$ \\
\hline & $(0.536)$ & $(0.852)$ & $(1.030)$ & $(0.397)$ & $(0.375)$ \\
\hline \multirow[t]{2}{*}{ Other ethnicity } & $-2.911 * * *$ & -0.236 & 0.191 & -0.389 & $-1.126 * *$ \\
\hline & $(0.527)$ & $(0.788)$ & $(0.975)$ & $(0.438)$ & $(0.456)$ \\
\hline \multirow[t]{2}{*}{ Constant } & $1.537 * *$ & $-2.745 * *$ & $-3.704 * * *$ & $-5.972 * * *$ & $-6.750 * * *$ \\
\hline & $(0.774)$ & $(1.303)$ & $(1.275)$ & (1.108) & $(1.301)$ \\
\hline Controls & YES & YES & YES & YES & YES \\
\hline Neighborhood fixed effect & YES & YES & YES & YES & YES \\
\hline Observations & 7,717 & 4,278 & 5,910 & 6,610 & 6,231 \\
\hline Number of neighborhoods & 262 & 242 & 279 & 271 & 210 \\
\hline R-squared & 0.152 & 0.291 & 0.327 & 0.509 & 0.613 \\
\hline Number of cluster & 262 & 242 & 279 & 271 & 210 \\
\hline
\end{tabular}


Table 7: OLS and state fixed effect estimates of the effects of the neighborhood-level proportion of adults with at least a secondary level education on years of formal education acquired by individuals 5-24 years old by ethnic group

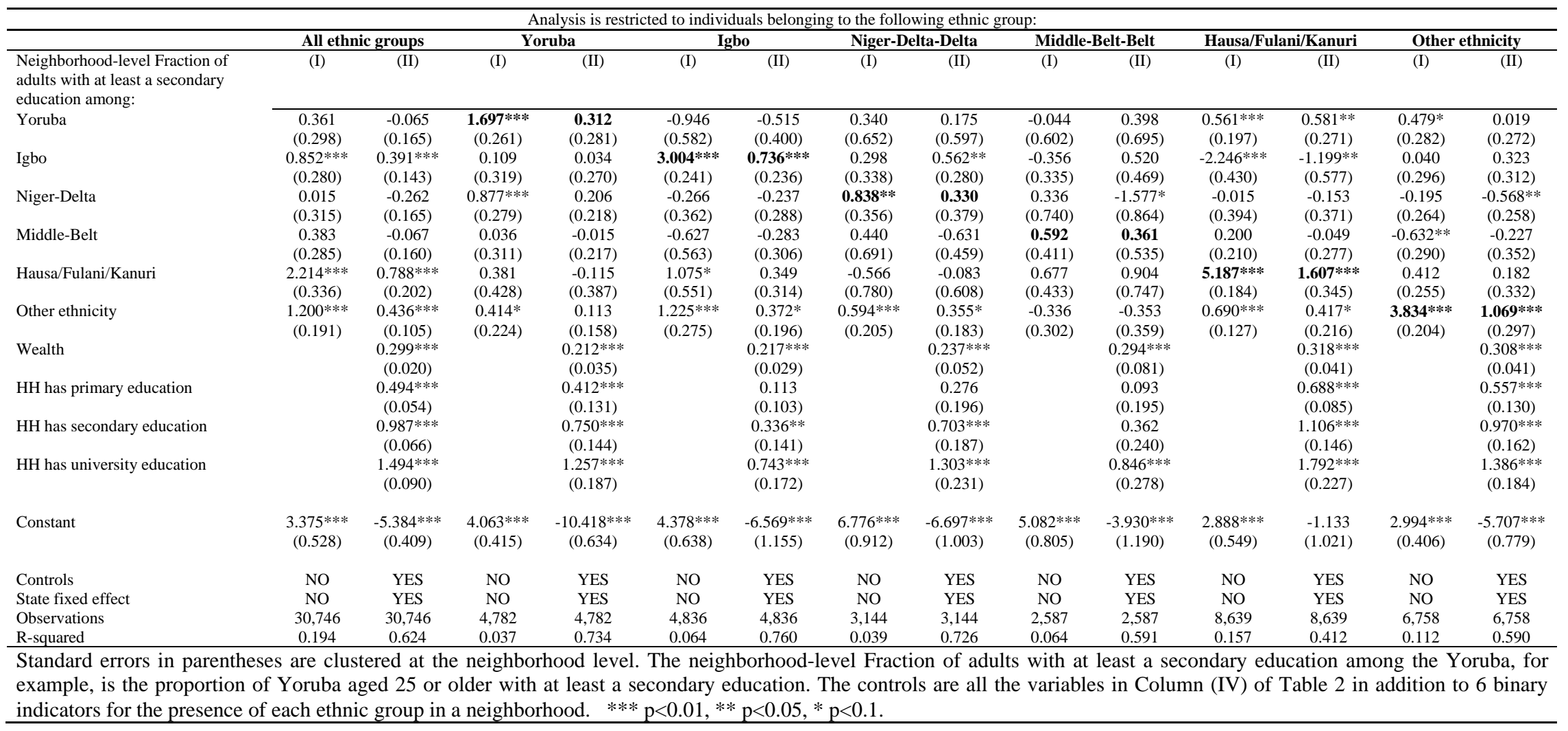


Table 8: OLS and state fixed effect estimates of the effects of the neighborhood-level proportion of adults with a university level education on years of formal education acquired by children 5-24 years old by ethnic group

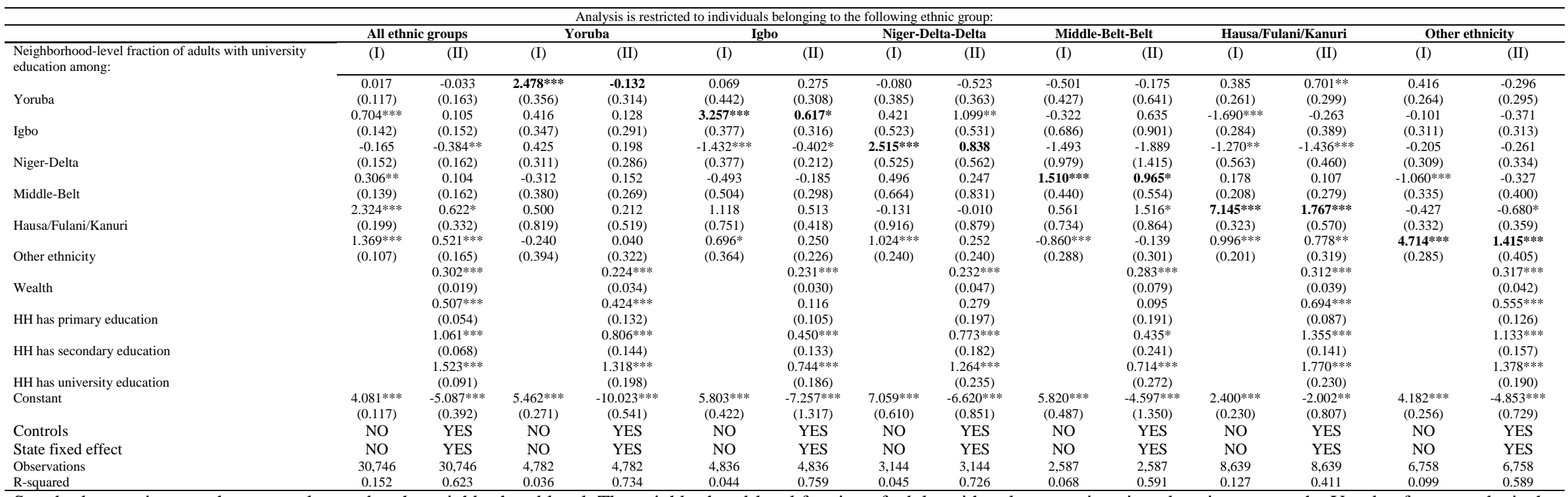

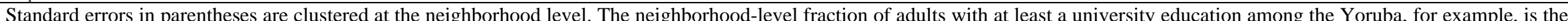

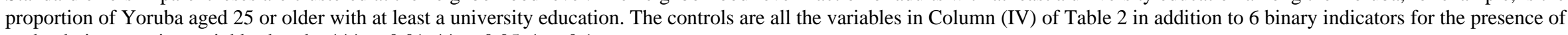
each ethnic group in a neighborhood. $* * * \mathrm{p}<0.01, * * \mathrm{p}<0.05, * \mathrm{p}<0.1$. 
Table 9: OLS and neighborhood fixed effect estimates of the effect of being an ethno-religious minority on years of formal education

\begin{tabular}{|c|c|c|c|c|c|c|}
\hline & (I) & (II) & (III) & (IV) & $(\mathrm{V})$ & $(\mathrm{VI})$ \\
\hline \multirow[t]{2}{*}{ Minority } & $0.932 * * *$ & $0.526 * * *$ & $0.509 * *$ & $0.343 * *$ & $0.526 * * *$ & $0.509 * *$ \\
\hline & $(0.190)$ & $(0.169)$ & $(0.210)$ & $(0.140)$ & (0.169) & $(0.210)$ \\
\hline \multirow[t]{2}{*}{ Igbo } & & -0.031 & -0.069 & & -0.031 & -0.069 \\
\hline & & $(0.177)$ & $(0.186)$ & & $(0.177)$ & $(0.186)$ \\
\hline \multirow[t]{2}{*}{ Niger-Delta } & & -0.056 & -0.112 & & -0.056 & -0.112 \\
\hline & & $(0.194)$ & $(0.202)$ & & $(0.194)$ & $(0.202)$ \\
\hline \multirow[t]{2}{*}{ Middle-Belt } & & $-0.673 * * *$ & $-0.721 * * *$ & & $-0.673 * * *$ & $-0.721 * * *$ \\
\hline & & $(0.190)$ & $(0.230)$ & & $(0.190)$ & $(0.230)$ \\
\hline \multirow[t]{2}{*}{ Hausa/Fulani/Kanuri } & & $-0.670 * * *$ & $-0.654 * * *$ & & $-0.670 * * *$ & $-0.654 * * *$ \\
\hline & & $(0.201)$ & $(0.224)$ & & $(0.201)$ & $(0.224)$ \\
\hline \multirow[t]{2}{*}{ Other ethnicity } & & $-0.288 *$ & $-0.293 *$ & & $-0.814 * * *$ & $-0.802 * * *$ \\
\hline & & $(0.149)$ & $(0.160)$ & & $(0.168)$ & $(0.180)$ \\
\hline \multirow[t]{2}{*}{ Minority*Igbo } & & & 0.988 & & & 0.988 \\
\hline & & & $(0.614)$ & & & $(0.614)$ \\
\hline \multirow[t]{2}{*}{ Minority*Niger-Delta } & & & $0.811^{* *}$ & & & $0.811^{* *}$ \\
\hline & & & $(0.393)$ & & & $(0.393)$ \\
\hline \multirow[t]{2}{*}{ Minority*Middle-Belt } & & & 0.127 & & & 0.127 \\
\hline & & & $(0.291)$ & & & $(0.291)$ \\
\hline \multirow[t]{2}{*}{ Minority*Hausa/Fulani/Kanuri } & & & -0.550 & & & -0.550 \\
\hline & & & $(0.613)$ & & & $(0.613)$ \\
\hline \multicolumn{2}{|l|}{ Minority*Other ethnicity } & & - & & & - \\
\hline Muslim & & $\begin{array}{c}-0.849 * * * \\
(0.162)\end{array}$ & $\begin{array}{c}-0.891^{* * *} \\
(0.188)\end{array}$ & & $\begin{array}{c}-0.849 * * * \\
(0.162)\end{array}$ & $\begin{array}{c}-0.891 * * * \\
(0.188)\end{array}$ \\
\hline \multirow[t]{2}{*}{ Constant } & $3.829 * * *$ & $-4.778 * * *$ & $-4.748 * * *$ & $3.814 * * *$ & $-4.778 * * *$ & $-4.748 * * *$ \\
\hline & $(0.091)$ & $(0.313)$ & $(0.314)$ & $(0.106)$ & $(0.313)$ & $(0.314)$ \\
\hline Controls & NO & YES & YES & NO & YES & YES \\
\hline Neighborhood fixed effect & NO & YES & YES & NO & YES & YES \\
\hline Observations & 30,746 & 30,746 & 30,746 & 30,746 & 30,746 & 30,746 \\
\hline Number of neighborhoods & 761 & 761 & 761 & 761 & 761 & 761 \\
\hline R-squared & 0.005 & 0.602 & 0.605 & 0.001 & 0.602 & 0.605 \\
\hline \multicolumn{7}{|c|}{$\begin{array}{l}\text { Standard errors in parentheses are clustered at the neighborhood level. The controls are all the variables in Column (V) of Table } 2 \text {. In Columns ( } \\
\text { (III), minority is a binary variable that takes the value of } 1 \text { if an individual is Muslim Igbo, Muslim Yoruba, Muslim Niger-Delta, Muslim Midd } \\
\text { Belt, or Christian Hausa/Fulani/Kanuri, and takes the value } 0 \text { otherwise. In Columns (IV)-(VI), minority is a binary variable that takes the value of } 1 \\
\text { an individual is Muslim Igbo, Muslim Yoruba, Muslim Niger-Delta, Muslim Middle-Belt, Christian Hausa/Fulani/Kanuri, or belongs to any of } \\
\text { other ethnicities, and takes the value } 0 \text { otherwise. }{ }^{* * *} \mathrm{p}<0.01, * * \mathrm{p}<0.05, * \mathrm{p}<0.1 \text {. }\end{array}$} \\
\hline
\end{tabular}


Table 10: OLS and state fixed effect estimates of the effects of neighborhood-level ethnic group size and ethnic fragmentation on years of formal education

\begin{tabular}{|c|c|c|c|c|c|c|c|c|c|}
\hline & (I) & (II) & (III) & (IV) & $(\mathrm{V})$ & (VI) & (VII) & (VIII) & $(\mathrm{IX})$ \\
\hline Population share of own ethnic group in the neighborhood & $\begin{array}{c}-1.543^{* * *} \\
(0.255)\end{array}$ & $\begin{array}{c}-1.278^{* * *} \\
(0.220)\end{array}$ & $\begin{array}{c}-0.209 * \\
(0.115)\end{array}$ & $\begin{array}{c}-0.227^{* *} \\
(0.115)\end{array}$ & & & & & $\begin{array}{c}0.046 \\
(0.123)\end{array}$ \\
\hline Neighborhood ethnic heterogeneity & & & & & $\begin{array}{c}2.304 * * * \\
(0.365)\end{array}$ & $\begin{array}{c}2.098 * * * \\
(0.295)\end{array}$ & $\begin{array}{l}0.314^{*} \\
(0.168)\end{array}$ & $\begin{array}{c}0.458 * * \\
(0.181)\end{array}$ & $\begin{array}{c}0.503^{* *} \\
(0.217)\end{array}$ \\
\hline Igbo & & $\begin{array}{c}-0.494 * * * \\
(0.169)\end{array}$ & $\begin{array}{c}-0.678 * * * \\
(0.097)\end{array}$ & $\begin{array}{c}-0.351 * * \\
(0.158)\end{array}$ & & $\begin{array}{c}-0.361^{* *} \\
(0.169)\end{array}$ & $\begin{array}{c}-0.661^{* * *} \\
(0.096)\end{array}$ & $\begin{array}{c}-0.334 * * \\
(0.156)\end{array}$ & $\begin{array}{c}-0.323^{* *} \\
(0.161)\end{array}$ \\
\hline Niger-Delta & & $\begin{array}{c}-0.453^{* *} \\
(0.193)\end{array}$ & $\begin{array}{c}-0.691 * * * \\
(0.123)\end{array}$ & $\begin{array}{c}-0.342 * * \\
(0.147)\end{array}$ & & $\begin{array}{c}-0.404^{* *} \\
(0.191)\end{array}$ & $\begin{array}{c}-0.688 * * * \\
(0.123)\end{array}$ & $\begin{array}{c}-0.333 * * \\
(0.146)\end{array}$ & $\begin{array}{c}-0.326^{* *} \\
(0.148)\end{array}$ \\
\hline Middle-Belt & & $\begin{array}{c}-1.874 * * * \\
(0.241)\end{array}$ & $\begin{array}{c}-1.072 * * * \\
(0.138)\end{array}$ & $\begin{array}{c}-0.812^{* * * *} \\
(0.136)\end{array}$ & & $\begin{array}{c}-1.836 * * * \\
(0.235)\end{array}$ & $\begin{array}{c}-1.071^{* * *} \\
(0.138)\end{array}$ & $\begin{array}{c}-0.805^{* * *} \\
(0.134)\end{array}$ & $\begin{array}{c}-0.800 * * * \\
(0.134)\end{array}$ \\
\hline Hausa/Fulani/Kanuri & & $\begin{array}{c}-4.014 * * * \\
(0.165)\end{array}$ & $\begin{array}{c}-1.629 * * * \\
(0.105)\end{array}$ & $\begin{array}{c}-1.338^{* * *} \\
(0.145)\end{array}$ & & $\begin{array}{c}-3.962^{* * * *} \\
(0.164)\end{array}$ & $\begin{array}{c}-1.630 * * * \\
(0.105)\end{array}$ & $\begin{array}{c}-1.349 * * * \\
(0.144)\end{array}$ & $\begin{array}{c}-1.347 * * * \\
(0.145)\end{array}$ \\
\hline Other ethnicity & & $\begin{array}{c}-1.994 * * * \\
(0.183)\end{array}$ & $\begin{array}{c}-0.881^{* * *} \\
(0.095)\end{array}$ & $\begin{array}{c}-0.504 * * * \\
(0.112)\end{array}$ & & $\begin{array}{c}-1.946 * * * \\
(0.181)\end{array}$ & $\begin{array}{c}-0.879 * * * \\
(0.095)\end{array}$ & $\begin{array}{c}-0.492 * * * \\
(0.111)\end{array}$ & $\begin{array}{c}-0.486 * * * \\
(0.113)\end{array}$ \\
\hline Constant & $\begin{array}{c}5.242 * * * \\
(0.225)\end{array}$ & $\begin{array}{c}6.693 * * * \\
(0.232)\end{array}$ & $\begin{array}{c}-4.584 * * * \\
(0.308)\end{array}$ & $\begin{array}{c}-4.878 * * * \\
(0.368)\end{array}$ & $\begin{array}{c}3.560 * * * \\
(0.137)\end{array}$ & $\begin{array}{c}5.213 * * * \\
(0.136)\end{array}$ & $\begin{array}{c}-4.797 * * * \\
(0.296)\end{array}$ & $\begin{array}{c}-5.107 * * * \\
(0.348)\end{array}$ & $\begin{array}{c}-5.158 * * * \\
(0.379)\end{array}$ \\
\hline Controls & NO & $\mathrm{NO}$ & YES & YES & $\mathrm{NO}$ & NO & YES & YES & YES \\
\hline State fixed effect & NO & NO & NO & YES & NO & NO & NO & YES & YES \\
\hline R-squared & 0.010 & 0.143 & 0.615 & 0.622 & 0.014 & 0.148 & 0.615 & 0.622 & 0.622 \\
\hline
\end{tabular}

